\title{
The deep distributions of helium isotopes, radiocarbon, and noble gases along the U.S. GEOTRACES East Pacific Zonal Transect (GP16)
}

William J. Jenkins ${ }^{1,2}$

Dempsey E. Lott III'

Christopher R. German ${ }^{3}$

Kevin L. Cahill ${ }^{2}$

Joanne Goudreau ${ }^{2}$

Brett Longworth ${ }^{3}$

1. Corresponding author, wjenkins@whoi.edu

2. Department of Marine Chemistry and Geochemistry, Woods Hole Oceanographic Institution, 266 Woods Hole Road, Woods Hole, MA 02543, U.S.A.

3. Department of Geology and Geophysics, Woods Hole Oceanographic Institution, 266 Woods Hole Road, Woods Hole, MA 02543, U.S.A.

\section{Abstract}

We report the deep distributions of noble gases, helium isotopes, and radiocarbon measured during the U.S. GEOTRACES GP16 East Pacific Zonal Transect between 152 and $77^{\circ} \mathrm{W}$ at $12-15^{\circ} \mathrm{S}$ in the South Pacific. The dominant feature is an intense tongue of hydrothermal effluent that extends more than $4,000 \mathrm{~km}$ westward from the East Pacific Rise (EPR) at $2500 \mathrm{~m}$ depth. The patterns reveal significant "downstream" variations in water mass structure, advection, and mixing that belie the simple perception of a continuous plume extending westward from the EPR. For example, one feature observed at $120^{\circ} \mathrm{W}, 14^{\circ} \mathrm{S}$ has tracer signatures that are consistent with a water mass originating from an area as much as 2,000 km south of this section, suggesting a quasi-permanent northward flow on the western flank of the EPR. Helium isotope variations in the plume show a uniquely high ${ }^{3} \mathrm{He} /{ }^{4} \mathrm{He}$ source in the tongue compared with typical mid-ocean ridge basalts (MORB), consistent with the anomalously high ratios observed in MORB glasses from the EPR segment just south of this transect. The water column data also reveal that the background ${ }^{3} \mathrm{He} /{ }^{4} \mathrm{He}$ east of the EPR is significantly lower than values characteristic of MORB, suggesting an additional, more geographically distributed radiogenic ${ }^{4} \mathrm{He}$ flux of order $10^{7} \mathrm{~mol} / \mathrm{y}$ into the deep Pacific.

In the western end of the section, incoming bottom waters have relatively less hydrothermal hydrothermal helium, more radiocarbon, and more oxygen, as well as negative saturation anomalies for the heavy noble gases ( $\mathrm{Ar}, \mathrm{Kr}$, and $\mathrm{Xe}$ ). During the basin-scale upwelling of this water, diapycnal mixing serves to erase these negative anomalies. The relative magnitudes of the increases for the heavy noble gases ( $\mathrm{Ar}, \mathrm{Kr}$, and $\mathrm{Xe}$ ) are quantitatively consistent with this process. This leads us to estimate the relatively smaller effects on He and Ne saturations, which range from near zero to $0.2 \%$ and $0.3 \%$ respectively. With this information, we are able to refine our estimates of the magnitude of ${ }^{3} \mathrm{He}$ and ${ }^{4} \mathrm{He}$ excesses and the absolute ${ }^{3} \mathrm{He} /{ }^{4} \mathrm{He}$ ratio of non-atmospheric helium introduced into deep Pacific waters. 


\section{Introduction}

The GEOTRACES program was envisioned as an international project to characterize the global scale ocean distributions of biogeochemically important trace elements and isotopes (TEIs) and to understand the processes that create and control those distributions. The U.S. GEOTRACES Eastern Pacific Zonal Transect was designed to probe at least two of those important processes: the influence of hydrothermal exchange at Mid Ocean Ridges (in particular here the East Pacific Rise), and the impact of a major ocean upwelling region off Peru. Here, we discuss our contribution to answering the former question while in an accompanying paper (Jenkins et al., 2017) we discuss the latter.

The circulation of seawater through hot, freshly formed ocean crust at seafloor spreading centers results in substantial modification of the chemistry of the seawater, and hence leads to substantial fluxes that are significant in the global ocean budgets of a number of elements (Edmond et al., 1979; Jenkins and Edmond, 1983; Elderfield and Schultz, 1996). This hydrothermal activity also injects significant amounts of the primordial isotope ${ }^{3} \mathrm{He}$ into the deep water (Clarke et al., 1969; Jenkins et al., 1978). Because of its inertness, paucity in the atmosphere due to ongoing loss to outer space (Stoney, 1905; Turekian, 1959; Axford, 1968; Patterson, 1968), and its low intrinsic solubility in seawater (Weiss, 1971), hydrothermal ${ }^{3} \mathrm{He}$ anomalies are observed throughout the deep oceans. As importantly, the distribution of the ${ }^{3} \mathrm{He}$ can be combined with tracer-calibrated ocean models to infer the global flux of hydrothermal ${ }^{3} \mathrm{He}$ to be $\sim 550 \mathrm{~mol} / \mathrm{y}$ (we obtain a weighted mean of $550 \pm 90 \mathrm{~mol} / \mathrm{y}$ from the estimates made by Bianchi et al., 2010; Schlitzer, 2016; Holzer et al., 2017). Measured in conjunction with critical TEls, we can use ${ }^{3} \mathrm{He}$ both as a "flux gauge" (Jenkins et al., 1978) and as a dilution tracer. In a simplistic model, deviations from a linear mixing relationship between ${ }^{3} \mathrm{He}$ and a TEI would signal consumption or production of that species. Part of this work (in particular some of the deep ${ }^{3} \mathrm{He}$ data west of the EPR) have been used to constrain the fluxes of long-lived hydrothermal Fe and Mn (Resing et al., 2015). Here we present the complete data set, along with measurements of radiocarbon and noble gases to provide further insight into the physicochemical processes affecting properties along this section. The hope is that this will lead to future synthesis of other's results and a better understanding of the global ocean behavior and budgets for many hydrothermally affected TEls. 


\section{Sampling and Measurement}

We collected samples as part of the U.S. GEOTRACES program (see http://www.geotraces.org/ ) on a section designated as GP16 in the eastern tropical South Pacific aboard the R/V Thomas G. Thompson October-December 2013. The location of stations occupied for these properties are shown in Figure 1.

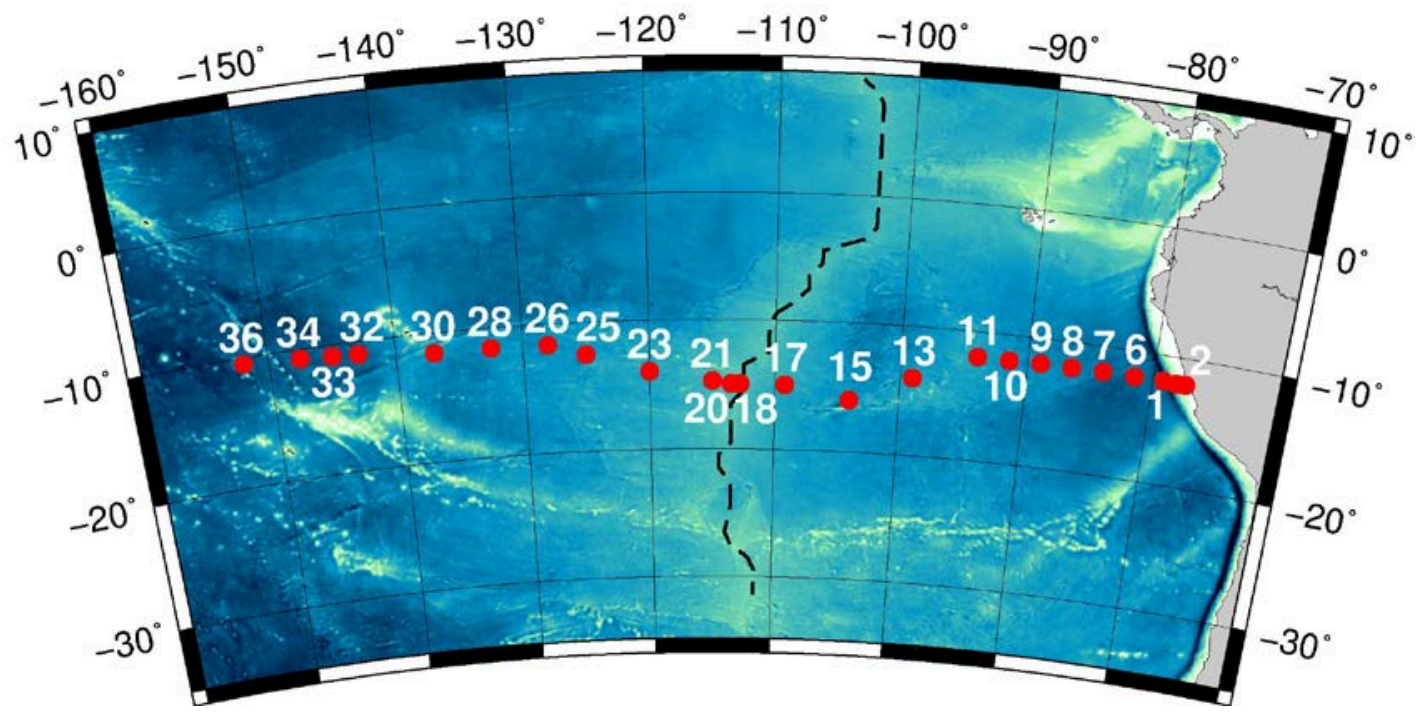

Figure 1: Station locations and numbers for the U.S. GEOTRACES EPZT cruise (GP16). Stations 3-5, are located between stations 2 and 1. The dashed line indicates the approximate location of the East Pacific Rise axis. This map was produced using GMT V4.5 (Wessel and Smith, 2008).

Samples were obtained from a 12 bottle-30 liter Niskin rosette operated by the Oceanographic Data Facility (https://scripps.ucsd.edu/ships/shipboard-technical-support/odf) ). Hydrographic data (station and cast locations and timing, sampling depths, pressure, temperature, salinity, dissolved oxygen, macronutrients, etc.) are available from the BCO-DMO (Biological and Chemical Oceanography Data Management Office http://www.bco-dmo.org/) as well as the CCHDO (CLIVAR and Carbon Hydrographic Data Office https://cchdo.ucsd.edu/cruise/325020131025 ) data repositories.

Helium isotope and noble gas water samples were sealed in duplicate 45 cc crimped copper tubing using the method of Young and Lupton (Young and Lupton, 1983) and returned for shore-based high vacuum extraction and mass spectrometric analysis using established methodology (Stanley et al., 2009a). Noble gas concentrations were measured by QMS ion current (dead-time corrected pulse counting) manometric comparison with precisely known atmospheric gas standards. Deviation from instrumental linearity was tested by the measurement of multiple gas aliquots and found to be zero within measurement errors. For a fraction of the samples, matrix effects (dependence on Ar and Xe contents) were found for $\mathrm{Kr}$ manometric measurements and corrected for empirically (Stanley, 2007). For the remainder of the samples, $\mathrm{Kr}$ and $\mathrm{Xe}$ measurements were improved by using ratiometric isotope dilution, where mono-isotopic $\mathrm{Kr}$ and Xe spikes $\left({ }^{78} \mathrm{Kr}\right.$ and $\left.{ }^{124} \mathrm{Xe}\right)$ were added to standards and unknowns and triple isotope ratios were used to correct for isotope fractionation in order to precisely compare unknowns to the running atmospheric standard. Aggregate measurement uncertainty for the helium isotope ratio anomaly was $0.15 \%$, and results were corrected for an empirically determined dependence of the observed isotope ratio on sample size. The noble gas abundances were determined to within 
$0.2 \%$ with the exception of the non-isotope dilution $\mathrm{Kr}$ and $\mathrm{Xe}$ measurements, which were only accurate to $0.3 \%$ for $\mathrm{Kr}$ and to $1 \%$ for $\mathrm{Xe}$. Uncertainties were determined by replicate water sample analyses and comparison to separate atmospheric gas standards.

Radiocarbon measurements were made on splits of $\mathrm{CO}_{2}$ gas samples extracted for $\delta^{13} \mathrm{C}$ analysis at the University of Washington and determined at the National Ocean Science Accelerator Mass Spectrometry (NOSAMS) Facility using standard AMS procedures (see http://www.whoi.edu/nosams) typically to an accuracy of 2.5 to $4.5 \%$ o for $\Delta^{14} \mathrm{C}$. The uncertainty estimates include both statistical (AMS counting) limitations and a "facility error" determined by inter-laboratory comparison of secondary standards.

All results were submitted to the designated U.S. GEOTRACES data repository, are publicly available from the BCO-DMO (http://www.bco-dmo.org/), and are expected to part of the GEOTRACES 2017 Intermediate Data Product (http://www.geotraces.org/dp/intermediate-data-product-2017 ).

\section{Results and discussion}

\section{a) The Deep Helium Distribution}

The zonal distribution of helium isotopes is shown as a function of depth in Figure 2. The upper panel depicts the helium isotope ratio anomaly $\delta^{3} \mathrm{He}$ relative to atmosphere in percent as defined by

$$
\delta^{3} \mathrm{He}=\left(\frac{\left({ }^{3} \mathrm{He} /{ }^{4} \mathrm{He}\right)_{\text {Sample }}}{\left({ }^{3} \mathrm{He} /{ }^{4} \mathrm{He}\right)_{\text {Air }}}-1\right) \times 100 \%
$$

The contour interval in $\delta^{3} \mathrm{He}$ is $5 \%$, which is more than 30 times the measurement error of $0.15 \%$. The section is dominated by the mid-depth $\left(\sim 2500 \mathrm{~m}\right.$ ) hydrothermal ${ }^{3} \mathrm{He}$ tongue extending from the East Pacific Rise (EPR) near $113^{\circ} \mathrm{W}$ for more than $4,000 \mathrm{~km}$ to the far western end of section at $152^{\circ} \mathrm{W}$ (where it still exceeds values of 30\%). This plume was first documented by Lupton and Craig (1981) and the comparison with historical data is the subject of another paper (Lupton and Jenkins, 2017). The westward direction of the plume runs counter the originally envisaged cyclonic abyssal flow by Stommel and Aarons (1960) but has been rationalized to be an abyssal anticyclone driven by mid-depth hydrothermal buoyancy injection, a so-called $\beta$-plume originally described by Stommel (Stommel, 1982; Hautala and Riser, 1993). This counterclockwise gyre appears to move northward over the EPR at around $110^{\circ} \mathrm{W}$ and swings westward at around $15^{\circ} \mathrm{S}$ carrying with it thermal and salinity anomalies (Reid, 1982) as well as excess ${ }^{3} \mathrm{He}$ (Lupton and Craig, 1981).

The maximum isotope ratio anomaly observed was almost $51 \%$, and attenuates westward. Away from the near-field injection site, the observed westward linear decrease in $\delta^{3} \mathrm{He}$ in relation to trace metals in the core of the plume (Resing et al., 2015; Roshan et al., 2016) is consistent with dilution. As a conservative tracer away from bomb tritium and hydrothermal sources, it is possible to estimate the global hydrothermal ${ }^{3} \mathrm{He}$ flux to be $\sim 550 \mathrm{~mol} / \mathrm{y}$ with some confidence (Bianchi et al., 2010; Schlitzer, 2016; Holzer et al., 2017), so such correlations may be used to estimate "persistent" hydrothermal fluxes for those metals. Clearly, however, the fidelity of such estimates depends how conservatively these TEI "phases" behave over large distances. As a more detailed three dimensional picture of the ${ }^{3} \mathrm{He}$ 
and TEI distributions emerge, we may be able to use the unambiguously conservative nature of ${ }^{3} \mathrm{He}$ away from hydrothermal (and tritium-decay) sources to discern such non-conservative behavior.

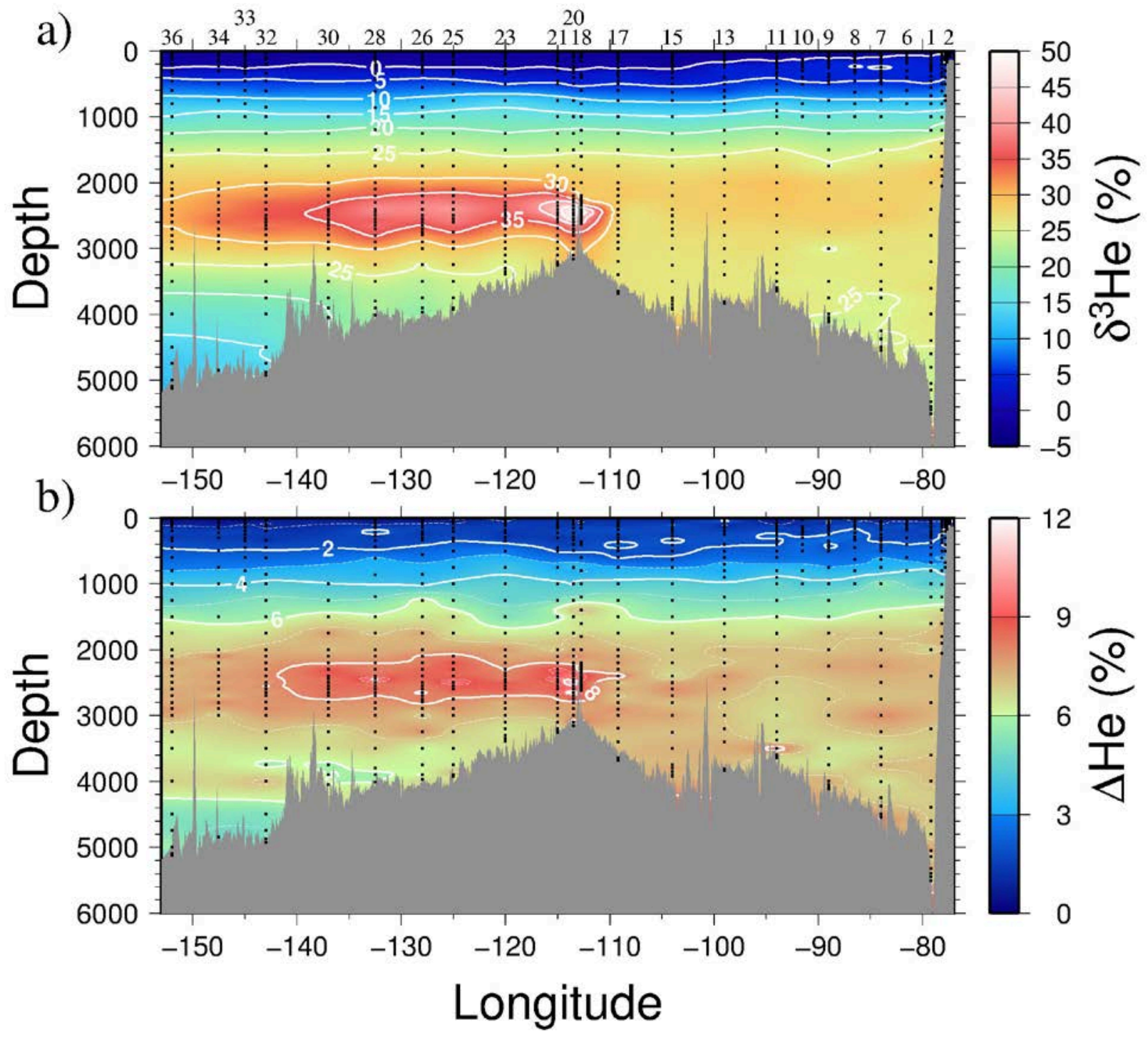

Figure 2: The zonal distributions of the observed (a) helium isotope ratio anomaly ( $8 \mathrm{He}$, upper panel, in \%) and (b) dissolved helium saturation anomaly ( $\Delta$ He, lower panel, in \%, as defined in Equation 4). Station numbers (excluding stations 3-5, which are situated between stations 2 and 1) are noted at the top. Black dots in these and later contour plots indicate sample locations. This and subsequent contour plots were produced using GMT 4. 5 (Wessel and Smith, 2008). 
Below the westward extending plume in Figure 2, the $\delta^{3} \mathrm{He}$ decreases to below $12 \%$ marking the influx of water from the south; some mixture of Circumpolar Deep Water and Antarctic Bottom Water. This is weakly mirrored by a more modest deep-ward decrease (to $\delta^{3} \mathrm{He} \sim 22-23 \%$, unfortunately not readily visible with the color pallet used but more readily visible in Figure 6 shown later) in the Peru-Chile trench near $79^{\circ} \mathrm{W}$, suggestive of some northward intrusion of a deep water mass there as well. Above the tongue, the $\delta^{3} \mathrm{He}$ decreases toward its atmospheric solubility equilibrium value (typically -1.6 to $1.8 \%$ ), with modest enhancements in the shallow layers due to in situ tritium decay (see Jenkins et al., 2017 for a discussion of the shallow features).

Examination of the average $\delta^{3} \mathrm{He}$ between 2250 and $2750 \mathrm{dbar}$, shown for each station as a function of longitude in Figure 3, reveals that the plume extends only a short distance eastward of the EPR axis, less than $350 \mathrm{~km}$ from station 18. The nearest upstream station (Station 17) to the EPR crest shows no significant increase above background, as defined by the stations further eastward. A non-conservative
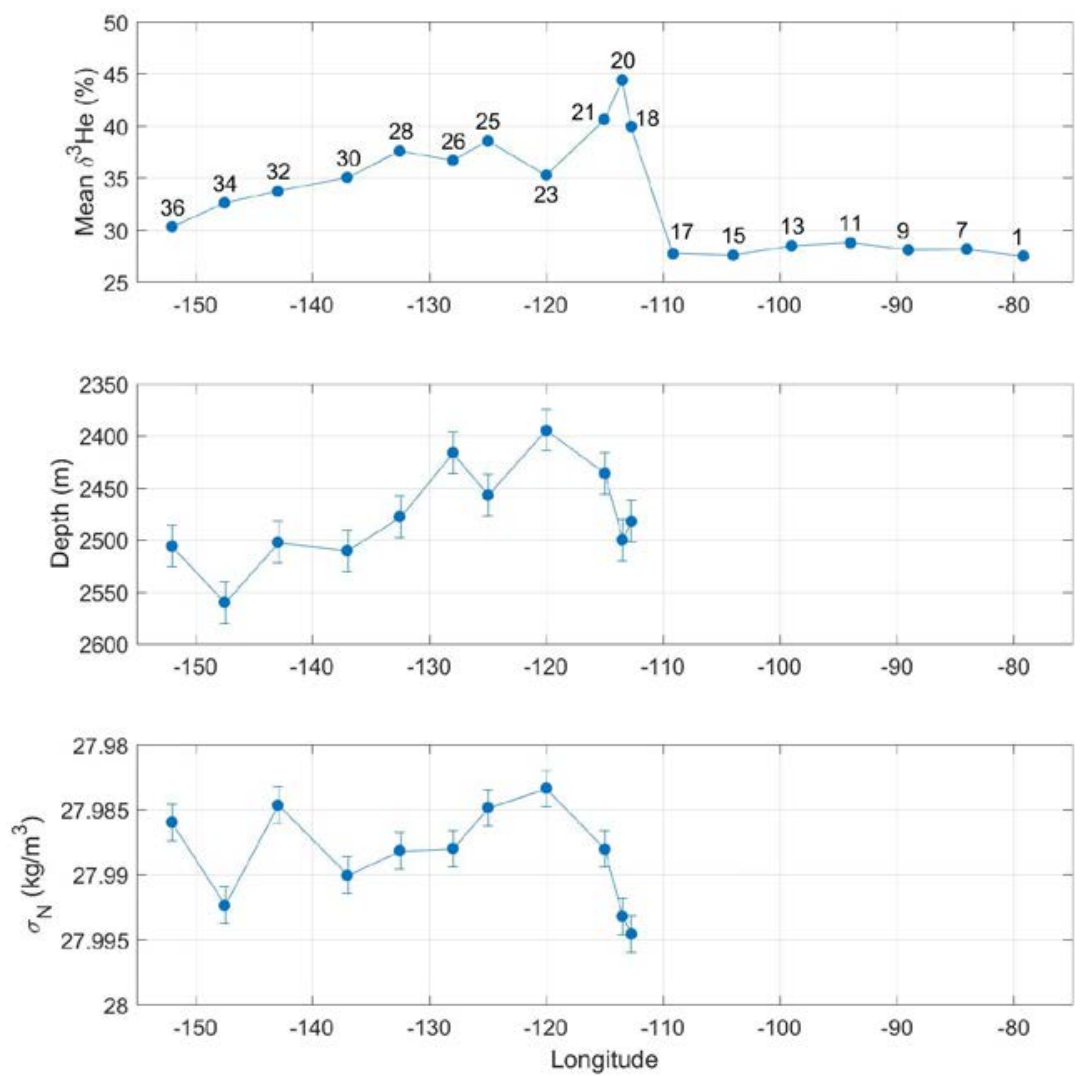

Figure 3: Top: the average 8 He between 2250 and 2750 dbar at each station, middle: plume depth, and bottom: the neutral density of the plume all as functions of longitude.

$\beta$-spiral calculation for velocities close to this locale (Hautala and Riser, 1993) yielded westward zonal flows velocities with $u \approx 1-3 \times 10^{-3} \mathrm{~m} \mathrm{~s}^{-1}$, so we can use the apparent lack of upstream propagation of $\delta^{3} \mathrm{He}$ by mixing over this distance $(L=350 \mathrm{~km})$ by using a simple scaling analysis to set a crude upper bound on the horizontal mixing rate $\kappa_{H}$ with 


$$
L \approx \sqrt{\kappa_{H} \frac{L}{u}} \Rightarrow \kappa_{H} \ll L \cdot u \approx 300-900 \mathrm{~m}^{2} \mathrm{~s}^{-1}
$$

Above and to the west of the EPR crest (at around $113^{\circ} \mathrm{W}$ ) the average $\delta^{3} \mathrm{He}$ decreases westward. As an exception, the intensity increases by a small amount over the short distance from station 18 to 20 (at 112.75 and $113.50^{\circ} \mathrm{W}$ ). Station 18 is situated right on the axis of the EPR while station 20 lies about 75 $\mathrm{km}$ to the west. While station 18 measures the local hydrothermal input intensity, station 20 reflects the integrated input from EPR segments to the south: the basin-scale anticyclonic (counterclockwise) circulation, as evidenced by large scale property distributions (Reid, 1982; Hautala and Riser, 1993) and predicted by theory (Stommel, 1982), sweeps northward along the EPR and veers westward around $15^{\circ} \mathrm{S}$. Moreover, observations of hydrothermal plumes along the EPR in this region show greater activity between $16^{\circ}$ and $20^{\circ} \mathrm{S}$ (Shimmield and Price, 1988; Baker and Urabe, 1996; Feely et al., 1996).

Note also the pronounced deficit in the westward decreasing trend at $120^{\circ} \mathrm{W}$, a feature hinted at in the $\delta^{3} \mathrm{He}$ contour lines in the upper panel of Figure 2. Such downstream "hiatuses" have been observed in this tongue before (see the contour structure in Figure 3 of Lupton et al., 2003) although not precisely at this same longitude. We discuss the significance of this hiatus within the context of plume depth below, and variations in the helium isotope ratio, radiocarbon, and other property distributions later.

Figure 3 also depicts the depth and neutral density of the plume maximum along with their estimated uncertainties as a function of longitude. These were determined by performing a quadratic fit of the 5 highest $\delta^{3} \mathrm{He}$ values for each profile as a function of depth or neutral density. A striking pattern emerges where the plume maximum at the four stations (numbers 20-26) west of the EPR crest appears to shoal by $50-75$ meters. This shoaling is also reflected in a significant decrease in neutral density. West of this there is a monotonic deepening of the plume maximum. These changes are not an artifact of vertical displacement of isopycnals, as the neutral density of the plume maxima change more-or-less in concert (from 27.995 to 27.984 to $\sim 27.993 \mathrm{~kg} / \mathrm{m}^{3}$, see lower panel). Such a displacement could arise from three possible causes. The first is a secular variation in hydrothermal intensity. It is well known that the buoyant plume height $(h)$ depends on the water column stratification and the net buoyancy flux (Morton et al., 1956; Speer and Rona, 1989; McDougall, 1990) according to

$$
h \propto F^{1 / 4} N^{-3 / 4}
$$

Where $F$ is the net buoyancy flux and $N$ is the background Brunt-Väisälä or buoyancy frequency (related to the background vertical stratification). Given the expected westward transit times of a few decades (Hautala and Riser, 1993 predicted zonal flows of order $0.1-0.5 \mathrm{~cm} / \mathrm{s}$ in this area), it is very unlikely that the latter factor will have changed significantly. Based on direct observations, the buoyant plume height at source is close to $200 \mathrm{~m}$. To increase the injection height by $50-75 \mathrm{~m}$ in the past would require a roughly 2.4 to 3.6 -fold increase in buoyancy flux, something which would not be considered feasible on the these time scales. Given the general anticyclonic nature of the regional circulation (Reid, 1982; Reid, 1986) the ${ }^{3} \mathrm{He}$ tongue likely integrates over a relatively large (few hundred $\mathrm{km}$ ) segment of the EPR, so such a modulation would require a significant change in volcanism over a large geographic scale or an even larger increase in a single vent field. Explanation of the deeper downstream subsidence by $100 \mathrm{~m}$ is more problematic: it would require a substantial (order of magnitude) weakening of the hydrothermal buoyancy flux in the past. 
A second explanation of the downstream depth changes would rely on the combination of circulation and geographic changes in EPR topography. That is, one might argue that the lateral plume is not a continuous downstream feature that follows our oceanographic section, but rather that our section cuts through different lateral plumes emanating from different parts of the EPR at different depths. Without a more detailed mapping of the three dimensional distribution of $\delta^{3} \mathrm{He}$ in this area coupled with a more complete knowledge the hydrothermal sources in relation to the EPR topography, this must remain speculation.

A third possibility is that mixing (both vertical and horizontal) may differentially erode the $\delta^{3} \mathrm{He}$ maximum in the vertical as the plume penetrates into the "background" hydrothermal ${ }^{3} \mathrm{He}$ and ${ }^{4} \mathrm{He}$ distribution. That is, the actual plume may not "migrate" upward or downward, but rather have its shape changed due to redistribution above and/or below. From the perspective of vertical mixing, a downward increase in mixing rates and/or stronger vertical gradients in $\delta^{3} \mathrm{He}$ might preferentially remove the $\delta^{3} \mathrm{He}$ signal from below, "pushing" the maximum upward during the initial half of its trajectory. Inspection of the $\delta^{3} \mathrm{He}$ profiles $v s$. depth in Figure 4 (left panel) reveals an essentially
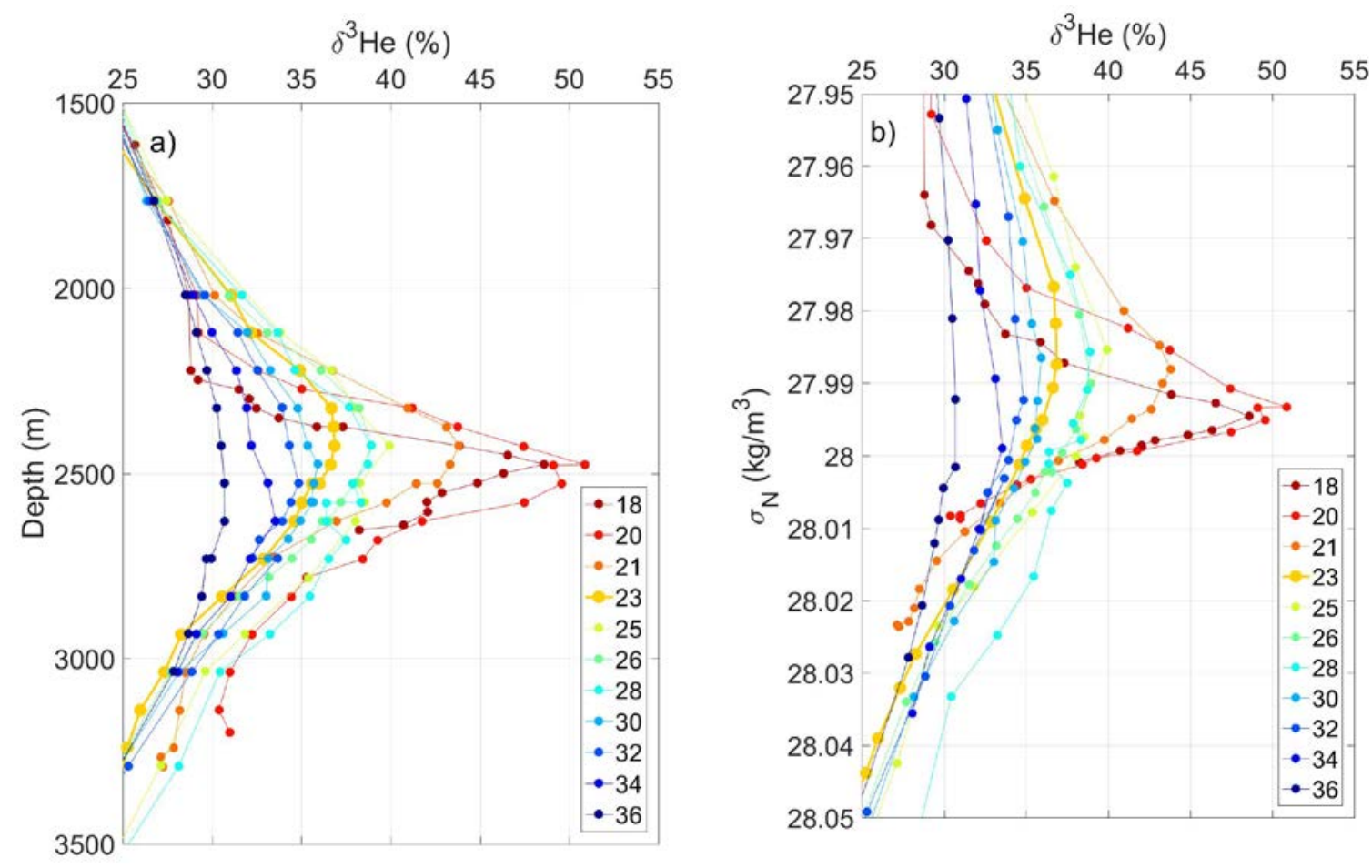

Figure 4: Station-by-station profiles of $\delta^{3} \mathrm{He}$ vs. (a) depth and (b) neutral density for the plume stations. The station numbers increase monotonically westward from the East Pacific Rise. Measurement errors are roughly the size of the symbols. Note that station 23 profile (yellow) has slightly larger symbols and thicker lines for emphasis.

vertically symmetric shape for most profiles, which rules out vertical changes in gradients as a significant contributing factor. Conversely, mid-ocean ridge flanks are regions characterized by bottom-enhanced vertical mixing (Polzin et al., 1997; Ledwell et al., 2000), so this may contribute to the apparent rise in the $\delta^{3} \mathrm{He}$ maximum. However, the anomalously high $\delta^{3} \mathrm{He}$ at Station 28 on the deeper neutral surfaces 
$\left(\sigma_{N}>28.00 \mathrm{~kg} / \mathrm{m}^{3}\right)$ belies this simplistic argument, suggesting that the westward deepening may be a reflection changes in the deep-water column due to circulation.

Returning to the plume "hiatus" at station $23\left(120^{\circ} \mathrm{W}\right)$, it should be noted the size of the $\delta^{3} \mathrm{He}$ anomaly (assuming a constant ${ }^{3} \mathrm{He}$ :heat ratio) is solely a function of the background vertical stratification (McDougall, 1990) which is unlikely to change in the deep water on decade time-scales. This, however, could suggest that the hiatus may have resulted from a temporary reduction in ${ }^{3} \mathrm{He}$ :heat ratio, something that has been observed elsewhere (Baker and Lupton, 1990). However, the shoaling of the maximum argues against it arising from a temporal reduction in hydrothermal intensity: such a reduction would have resulted in deepening of the maximum. Note that the plume "hiatus" (station 23, indicated by yellow symbols) stands out in the respect that it "falls between" stations 28 and 30, almost as if it were displaced eastward by $1500 \mathrm{~km}$. However, such a displacement is at odds with what we know about the large-scale flow patterns for this region (see, for example Reid, 1982; Reid, 1986; Hautala and Riser, 1993). Moreover, as shall be seen in our later discussion, the distributions of other properties suggest a rather different origin.

The hydrothermal tongue is also evident in the saturation anomaly of dissolved helium, shown here in the lower panel in Figure 2 and defined by

$$
\Delta \mathrm{He}=100 \times\left(\frac{C(\mathrm{He})}{C_{S}(\mathrm{He})}-1\right) \%,
$$

where $C(\mathrm{He})$ is the measured molar concentration of helium and $C_{S}(\mathrm{He})$ is the solubility concentration in equilibrium with 1 atmosphere moist air at the potential temperature and salinity of the sample. The contour interval is $2 \%$, large compared with a measurement uncertainty of $0.2 \%$. The large scale features in $\delta^{3} \mathrm{He}$ are reflected in the $\Delta \mathrm{He}$ distribution; namely the mid-depth hydrothermal plume extending westward from the crest of the EPR, underlain in the west by incoming low $\Delta$ He waters, a more subtle effect in the Peru-Chile trench at the eastern end of the section, and a general decrease upward through the thermocline to low values ( $1 \%$, sustained by wind/wave induced bubble injection) at the surface. The fact that the hydrothermal ${ }^{3} \mathrm{He}$ tongue is reflected in excess helium $(\Delta \mathrm{He})$ arises because the hydrothermal helium input is not pure ${ }^{3} \mathrm{He}$ but is actually helium with an elevated ${ }^{3} \mathrm{He} /{ }^{4} \mathrm{He}$ ratio, expected to be of order 8 times the atmospheric ratio, as observed in Mid Ocean Ridge Basalts (e.g., see Kurz and Jenkins, 1981).

\section{b) The Deep Radiocarbon Distribution}

Figure 5 shows the radiocarbon section. In an accompanying paper (Jenkins et al., 2017), we discuss the shallow distribution of radiocarbon restrict our comments here to the deeper features. As was known from the earliest observations (Bien et al., 1960; Bien et al., 1965), the deep distribution of $\Delta^{14} \mathrm{C}$ in the Pacific is dominated by a mid-depth (2000-3000 m) minimum. This minimum results from the incursion below $4000 \mathrm{~m}$ in the west of younger, higher $\Delta^{14} \mathrm{C}$ waters ultimately derived from Antarctic Bottom and North Atlantic Deep Waters (Ostlund and Stuiver, 1980; Schlitzer, 2007). The intensity of this minimum is governed by a balance between cumulative decay along the global thermohaline overturning circulation (Kuhlbrodt et al., 2007; Schlitzer, 2007), distributed upwelling to intermediate depths (Munk, 
1966), in situ remineralization of relatively modern carbon from the rain of particulate material from above (Craig, 1969), and mediated by vertical mixing (Munk, 1966; Craig, 1969).

Although there is an expected east-west asymmetry in the deep $\Delta^{14} \mathrm{C}$ (that is, higher $\Delta^{14} \mathrm{C}$ in the west) consistent with deep circulation, the deepest waters in the easternmost end of the section also show the invasion of relatively young bottom waters with the deepest sample in the trench reaching -206\%. (Note the closed $-220 \%$ contour at $3500 \mathrm{~m}$ and $85-90^{\circ} \mathrm{W}$ is likely an artifact of the contouring algorithm, which should extend the $-220 \%$ o contour at 4000 m upward.) On the basis of hydrographic and composite nutrient tracers, Peters et al. (Peters et al., 2017) designate this as "Lower Circumpolar Deep Water" (LCDW). According to the circulation scheme proposed by Lonsdale (see Figure 1 of Lonsdale, 1976) this water enters the Chile Basin through gaps in the eastern Chile Rise and subsequently flows northward into the Peru basin through the Peru Trench and gaps in the Nazca Ridge. The northward flow is also evident at $32^{\circ} \mathrm{S}$ in the inversions of Wijffels et al. (seen in Figure 5 of Wijffels et al., 2001). As mentioned before, there is a corresponding decrease of $\delta^{3} \mathrm{He}$. Considering the "source" LCDW characteristics of $\delta^{3} \mathrm{He}=10.5 \%$ (at $\sim 62^{\circ} \mathrm{S}$ and $\sim 105^{\circ} \mathrm{W}$ from WOCE P18) and $\Delta^{14} \mathrm{C}=-160 \%$ (at $\sim 64^{\circ} \mathrm{S}$ and $\sim 103^{\circ} \mathrm{W}$ from WOCE P17S) this is consistent with the water mass composition map of Peters et al (2017) for the Peru-Chile trench.

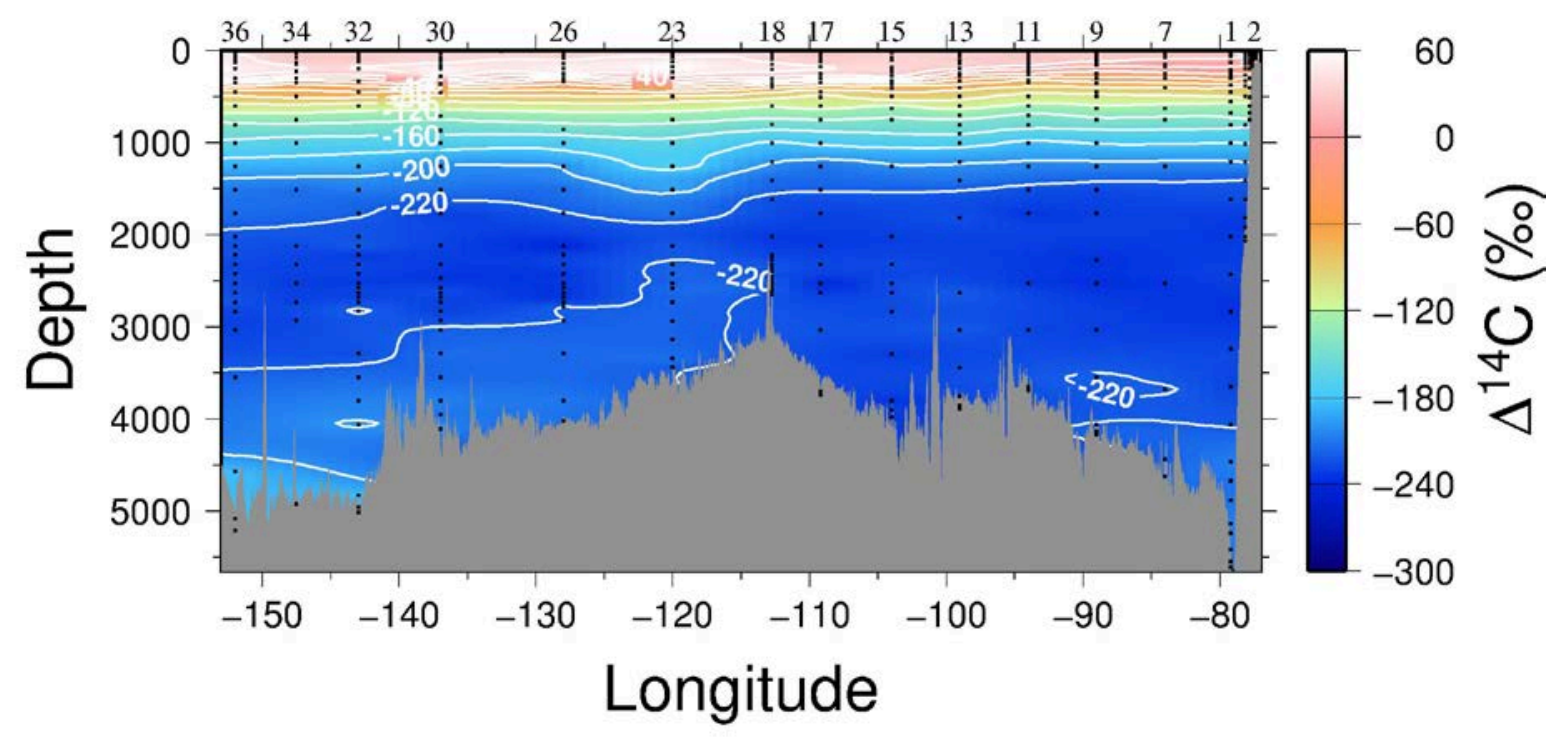

Figure 5: The observed deep $\Delta^{14} \mathrm{C}$ (in \%o) section. Contour interval is 20\%o compared to an average uncertainty of $\sim 2-3 \%$ in the deep water.

In Figure 6, we show the zonal distributions of (a) $\delta^{3} \mathrm{He}$ (in \%), (b) $\Delta^{14} \mathrm{C}$ (in \%o), (c) silicate (in $\mu \mathrm{mol} / \mathrm{kg}$ ), and (d) dissolved oxygen (in $\mu \mathrm{mol} / \mathrm{kg}$ ) plotted against neutral density (as defined by Jackett and McDougall, 1997). The enhanced color scheme further emphasizes the bottom-water invasion of 
younger, lower $\delta^{3} \mathrm{He}$, higher $\Delta^{14} \mathrm{C}$, and higher oxygen waters on the western and eastern ends of the

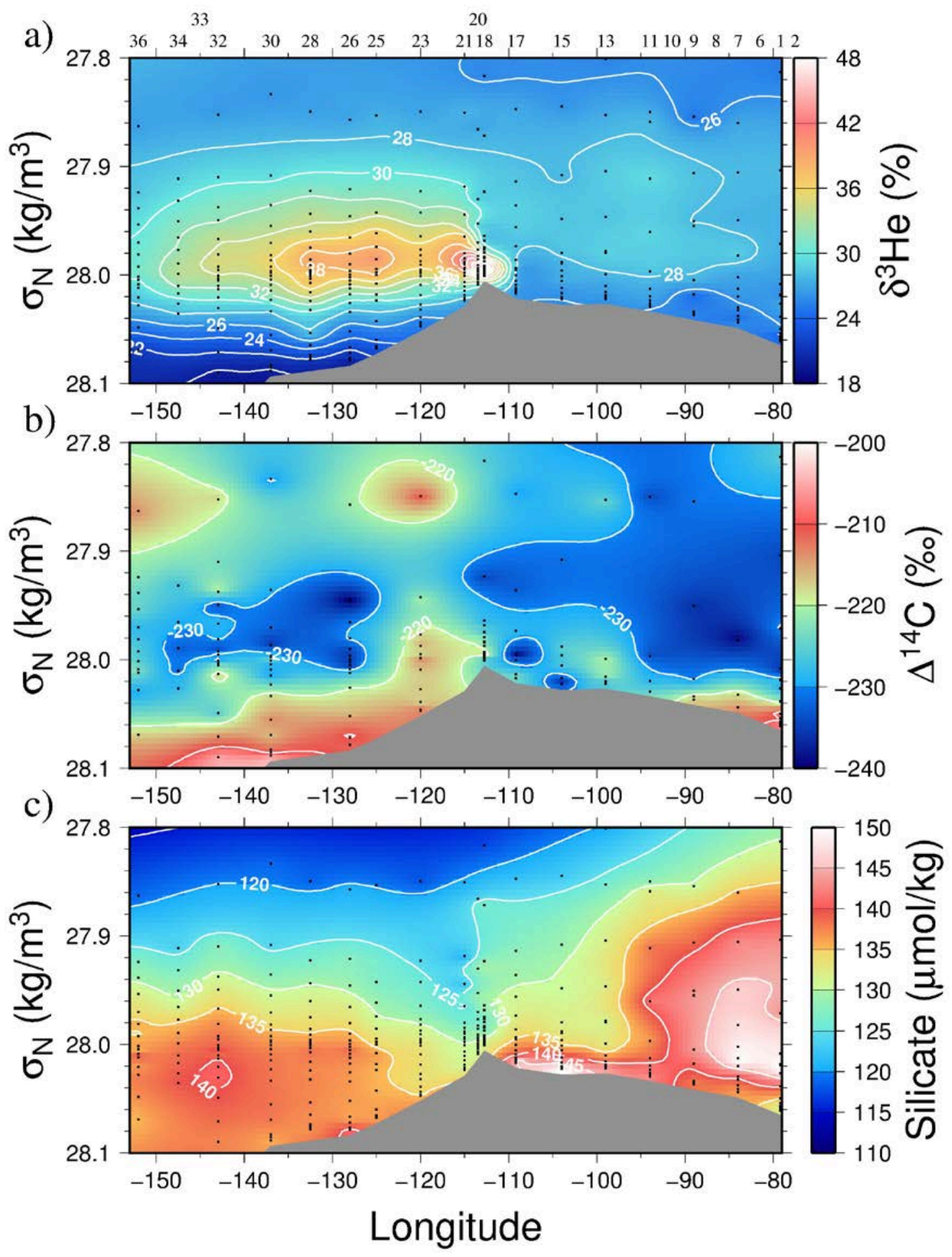

Figure 6a-c: The zonal distributions of (a) $\delta^{3} \mathrm{He}$ (upper panel in \%), (b) radiocarbon $\Delta^{14} \mathrm{C}$ (middle panel, in \%o) and (c) silicate (lower panel, in $\mu \mathrm{mol} / \mathrm{kg}$ ) plotted as a function of neutral density (in $\mathrm{kg} / \mathrm{m}^{3}$ ). Note that the color scales for) $\delta^{8} \mathrm{He}$ and $\Delta^{14} \mathrm{C}$ differ from those in Figures 2 and 5 respectively. 


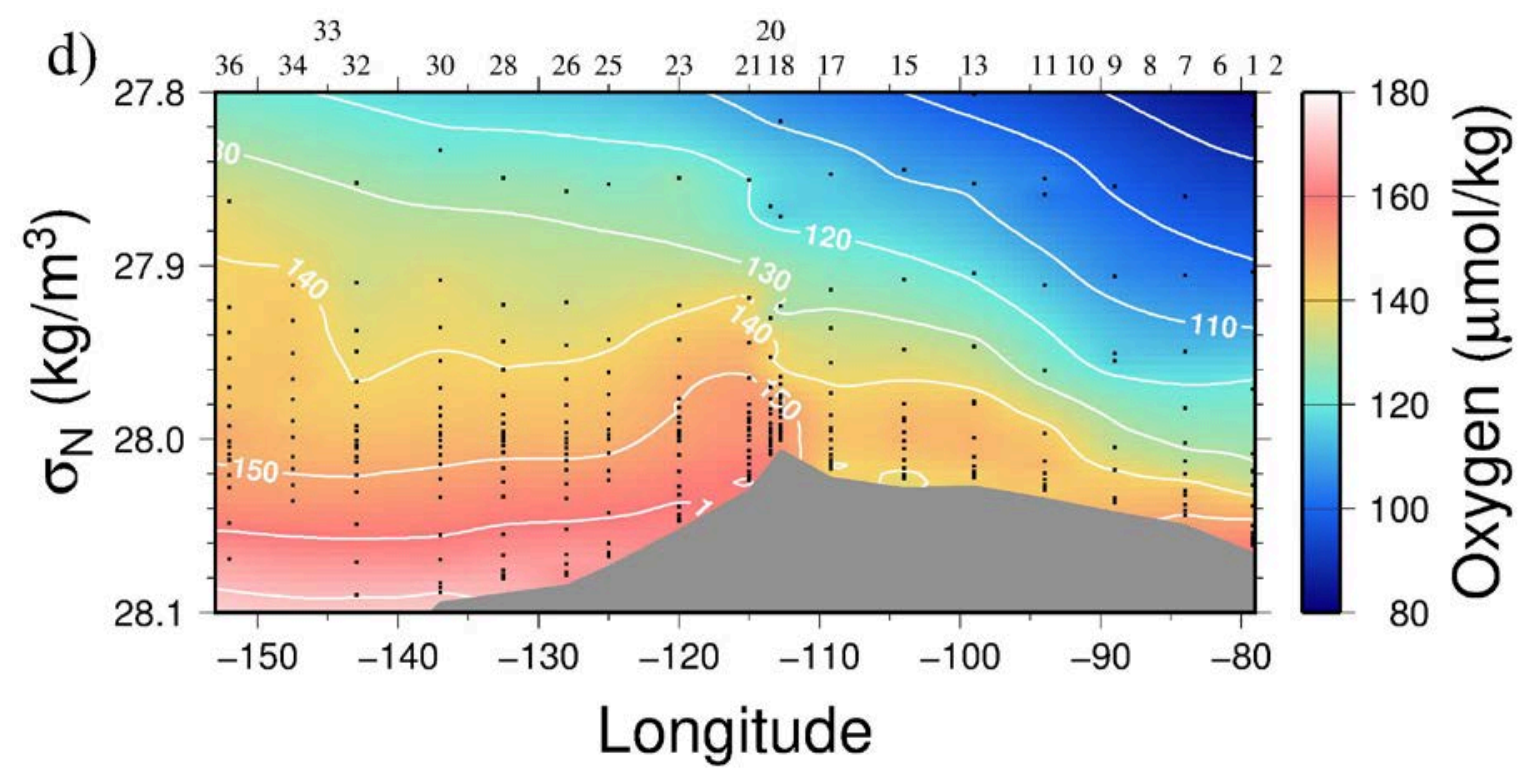

Figure 6d: The zonal distribution of (d) dissolved oxygen (in $\mu \mathrm{mol} / \mathrm{kg}$ ).

section. The silicate distribution is apparently more complicated, with evidence of a near bottom enhancement just east of the EPR crest $\left(100-110^{\circ} \mathrm{W}\right)$ and a mid-depth maximum in the eastern basin that is reminiscent of the $\Delta^{14} \mathrm{C}$ minimum and underlain by slightly lower silicate (higher oxygen, higher $\Delta^{14} \mathrm{C}$, lower $\delta^{3} \mathrm{He}$ ) waters in the Peru-Chile trench.

The $\delta^{3} \mathrm{He}$ plume extends westward from $113^{\circ} \mathrm{W}$ along the $27.990 \pm 0.005 \mathrm{~kg} / \mathrm{m}^{3}$ neutral surface, with a distinct local zonal minimum at around $120^{\circ} \mathrm{W}$. This minimum is marked by a corresponding maximum in $\Delta^{14} \mathrm{C}$ (middle panel) exceeding -220\%o over a significant neutral density range, suggesting that the zonal modulation of the lateral plume (i.e., the deviation from a monotonic westward decrease in ${ }^{3} \mathrm{He}$, see Figures 2-4) arises from a meridional displacement of water masses rather than some decade time-scale reduction of hydrothermal activity. Moreover, the depth and lighter neutral density of the $\delta^{3} \mathrm{He}$ maximum at this station ( $50 \mathrm{~m}$ shallower and $\sim 0.01 \mathrm{~kg} \mathrm{~m}^{-3}$ lighter than the upstream portion of the dispersing plume, see Figure 3 ) would require a substantial increase in hydrothermal activity, not a cessation. Thus instead, we conclude that this feature must result from circulation.

The radiocarbon "anomaly" of $~ 15 \%$ associated with the decrease in excess ${ }^{3} \mathrm{He}$ is substantially larger than measurement precision for a single sample (2.6\%), and given that the anomaly shows significant spatial coherence, extending vertically over several samples, we must conclude that it is real. There appears to be a counterpoint response in the silicate distribution at this location (Figure 6c) in that the silicate 125 and $130 \mu \mathrm{mol} / \mathrm{kg}$ isopleths extend downward in this region. This feature, however, extends further toward the EPR than the $\Delta^{14} \mathrm{C}$ isopleths. Part of this disparity may be an artifact of contouring/data resolution (the lateral spacing of radiocarbon stations is sparser than that of silicate and $\delta^{3} \mathrm{He}$ ), but it may also be a reflection of the locally complex circulation induced by the hydrothermal buoyancy injection and topography (Stommel, 1982; Hautala and Riser, 1989; Speer, 1989; Hautala and Riser, 1993; Thurnherr et al., 2011). 
Johnson and Talley (1997) show a deep salinity anomaly centered at $120^{\circ} \mathrm{W}$ along $15^{\circ} \mathrm{S}$ (their Plate 1 (a)) that is suggestive of meridional transport off-axis of the EPR. Figure 7 shows mid-depth profiles of some properties at Station 23 (the ${ }^{3} \mathrm{He}$ minimum at $120^{\circ} \mathrm{W}$ ). Notably there appears to be an inflection in all of these profiles between $\sim 2250$ and $\sim 2750 \mathrm{dbar}$, suggesting an intrusion of a foreign water mass in that

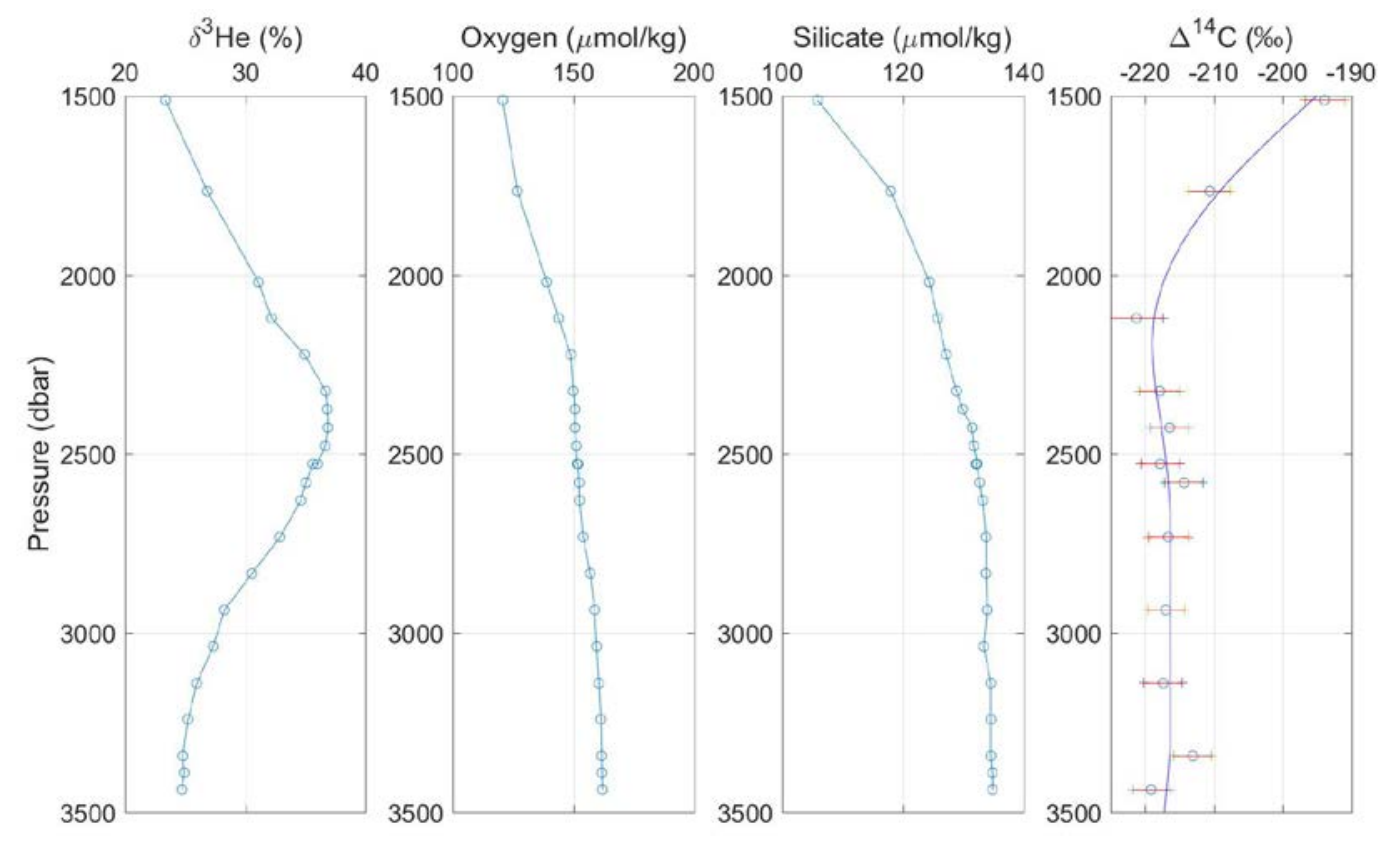

Figure 7: Mid-depth property profiles for station 23 , the $120^{\circ} \mathrm{W}$ plume minimum.

range. From what we know about the large-scale abyssal distribution of radiocarbon (Ostlund and Stuiver, 1980; Key, 1996; Key et al., 1996; Schlitzer, 2007), in particular the mid-depth (2500 m) meridional gradients, we conclude that this water must have come from the south, perhaps as far south as $30-35^{\circ} \mathrm{S}$.

Considering the tracer information, we may be emboldened to hazard a guess as to its origins. Figure 8 shows the zonal distributions of (a) silicate, (b) radiocarbon, and (c) $\delta^{3} \mathrm{He}$ along WOCE line P06 at $32^{\circ} \mathrm{S}$. A qualitative comparison of the mid-depth property distributions are suggestive of an origin near $110^{\circ} \mathrm{W}$ but the silicate at station 23 is perhaps $10 \mu \mathrm{mol} / \mathrm{kg}$ too high. This could be rationalized by assuming that the water somewhat westward of this locale with slightly lower $\delta^{3} \mathrm{He}$ could pick up additional silica and hydrothermal ${ }^{3} \mathrm{He}$ in its transit northward to GEOTRACES section, while the effect of ${ }^{14} \mathrm{C}$ decay on $\Delta{ }^{14} \mathrm{C}$ may be partially balanced by in situ remineralization of modern carbon from above (Craig, 1969).

The question arises as to whether there is additional evidence of northward transport roughly paralleling the western flank of the EPR. In analyzing deep circulation in the region of interest, Hautala and Riser (1993) comment that "Mortlock's isopycnal maps show a distinct low silicate 'finger' penetrating northward ... along the East Pacific Rise to about $14^{\circ} \mathrm{S}$ ". This feature is convincingly echoed in maps of the radiocarbon-based deep water age (see Figure 4 of Matsumoto, 2007), where around $110-120^{\circ} \mathrm{W}$ a tongue of younger water extends northward from $30-40^{\circ} \mathrm{S}$ to nearly the equator. The Matsumoto feature is further supported by a nuanced analysis deep radiocarbon ages by Gebbie and Huybers (2012, note the northward excursion of the 900 year isochron near 110-120W in the top left panel of their figure 7). Physically, such a flow along the flank of the East Pacific Rise can be expected on 
the basis of $f / H$ (Coriolis parameter divided by ocean depth) control of barotropic flow (Pedlosky, 1979) and indeed it appears in global (see Plate 1 of Koblinksy, 1990) and regional (see figure 17 of Hautala and Riser, 1993) maps.

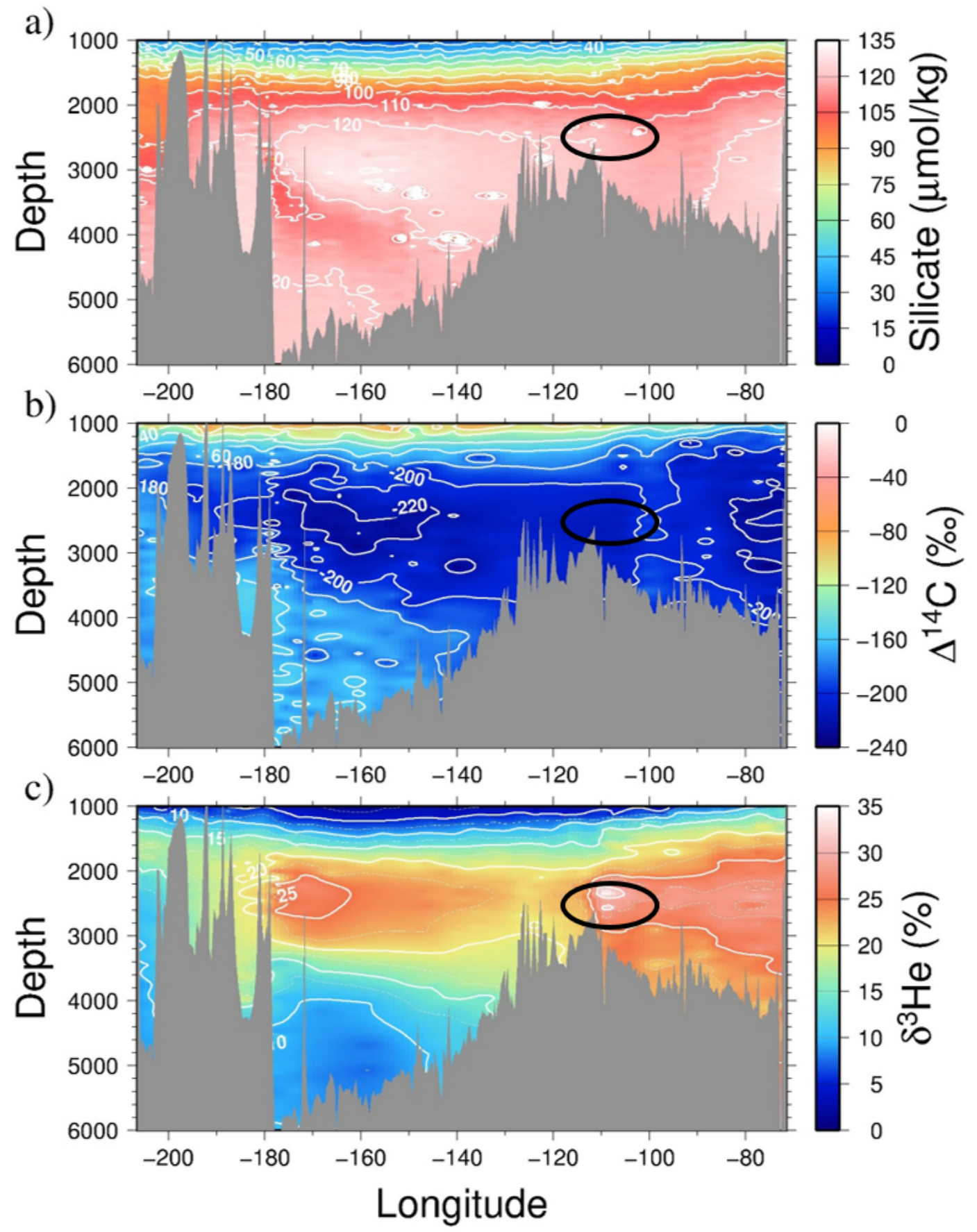

Figure 8: The deep zonal distributions of (a) silicate (upper panel), (b) radiocarbon (middle panel), and (c) $8 \mathrm{He}$ (lower panel) along 32 S (WOCE Line P06) measured in 1992 and 2010. The black ellipse marks the approximate location of where the anomalous water may come from. 
Finally, one might be inclined to model the downstream evolution of $\Delta^{14} \mathrm{C}$ associated with the westward propagation of the hydrothermal plume. However, this is confounded by the presence of significant meridional flows, as evidenced by the hiatus at Station 23, and the non-monotonic behavior of the $\Delta^{14} \mathrm{C}$ and plume depth trends vs. longitude. Moreover, there is also a significant westward decrease west of the EPR crest in dissolved oxygen at the neutral density of the plume maximum (around $\sigma_{N}=27.99 \mathrm{~kg} \mathrm{~m}^{-3}$ in Figure $6 \mathrm{~d}$ ), which implies in situ remineralization of relatively modern carbon from above.

\section{c) The Deep Noble Gas Distributions}

The distributions of dissolved noble gases ( $\mathrm{He}, \mathrm{Ne}, \mathrm{Ar}, \mathrm{Kr}$, and $\mathrm{Xe}$ ) in the deep ocean are governed by air-sea exchange processes in the formation regions of the water masses (Stanley et al., 2006; Hamme and Severinghaus, 2007) coupled with ocean circulation and mixing (Ito and Deutsch, 2006; Ito et al., 2007). Since the solubilities of the noble gases in seawater are more-or-less strongly dependent on temperature (and to lesser extent on salinity), it is common practice to present the results as saturation anomalies. These are defined (in percent) relative to concentrations expected at equilibrium with one atmosphere moist air at the potential temperature and salinity of the sample in fashion analogous to Equation 4 for $\Delta \mathrm{He}$. Note that we use empirically determined solubility functions for the noble gases based on recent experiments in our laboratory (see http://www. whoi.edu/sites/IGF where the experimental description and MATLAB m-files are available). We do this for consistency: the solubilities for all gases were determined in the same laboratory using the same methods of equilibration, the same atmospherically linked standards, and the same analytical methods. Moreover, the solubilities are determined at actual oceanic concentration levels to avoid extrapolation over a broad range of partial pressures (e.g., from one atmosphere to $~ 1 \times 10^{-6}$ atmosphere for $\mathrm{Kr}$ ). In addition, the measurements were made in reference to atmospheric standards using the same assumed atmospheric abundances we used for seawater measurements, so that any systematic uncertainty in the latter values will cancel out. We present the distributions of these anomalies in Figure 9a-d. Note that for the Xe data, we only plot those measurements made after procedural improvements using ratiometric isotope dilution, since the earlier, lower precision peak height manometry measurements for Xe were only good to $1 \%$. See Figure $2 \mathrm{~b}$ (lower panel) for the corresponding saturation anomalies for He. 


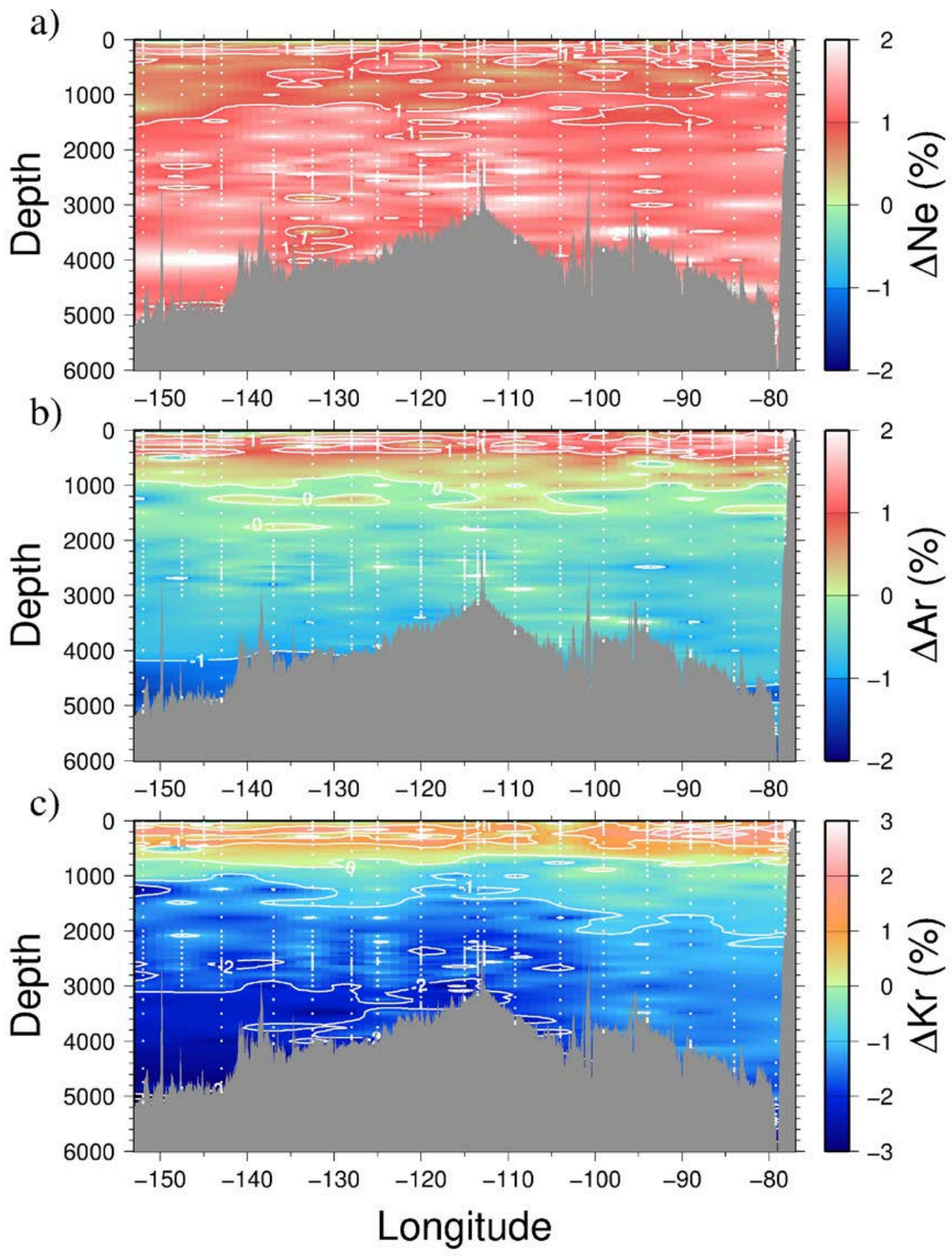

Figure 9a-c: The deep zonal distributions of noble gas saturation anomalies, including a) Ne (upper panel), b) Ar (middle panel) and c) Kr (lower panel). Measurement uncertainties are $0.2 \%$ for Ne and $A r$, and between 0.2 and $0.3 \%$ for $K r$. Note the color scale difference for $\Delta K r$. 


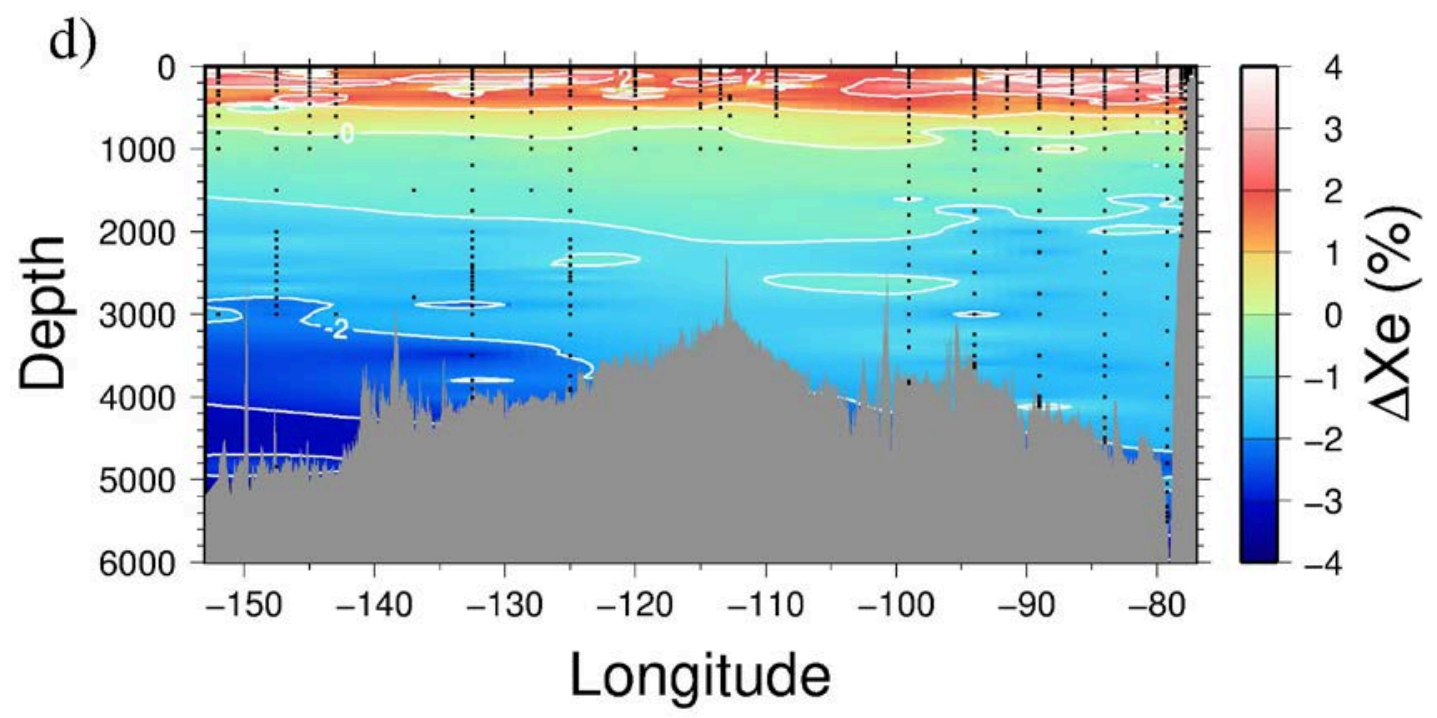

Figure 9d: The deep zonal distributions of Xe saturation anomalies for ratiometric isotope dilution measurements only. Uncertainties are 0.2 to $0.3 \%$. Note the different color scale for $\Delta X e$. The area below $3200 \mathrm{~m}$ west of $135^{\circ} \mathrm{W}$ is indeterminate due to lack of high quality measurements, but the extrapolated low values are borne out by the lower precision measurements (not shown).

The $\Delta \mathrm{He}$ distribution (see Figure 2, lower panel) has the added complication of volcanic/hydrothermal introduction at the seafloor, and the observed distribution of $\Delta$ He bears a strong resemblance to that of $\delta^{3} \mathrm{He}$. Indeed, a histogram of the $\Delta \mathrm{He}$ distribution (Figure 10 ) shows a bimodality reflecting the two dominant origins of helium supersaturation: bubble injection at the sea surface during water mass formation (a peak at 1-2\%) and hydrothermal injection (a broader peak at 7-8\%) in the deep water. In contrast, the distribution of $\Delta$ Ne shows an essentially normal distribution centered around $1.1 \%$ (Figures 10 and 11 ), with standard deviation of $0.4 \%$, significantly larger than measurement error of $0.2 \%$. The neon mean saturation anomaly is somewhat lower (by about $0.7 \%$ ) than that reported for Hamme and
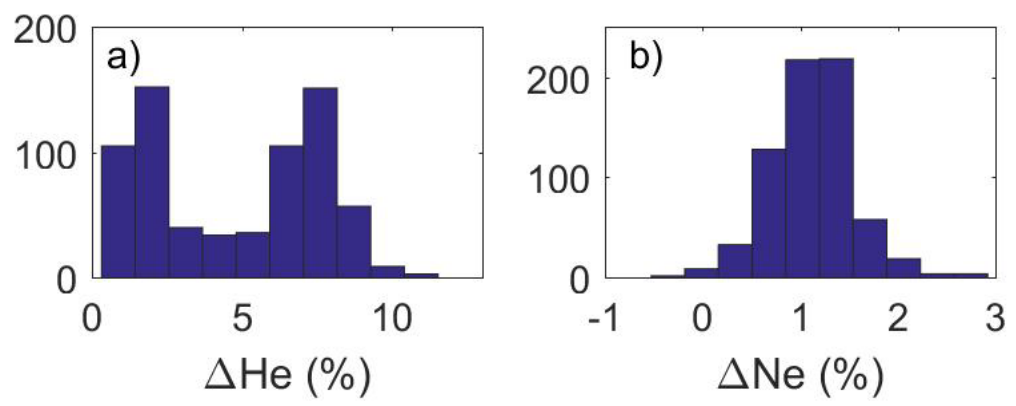

Figure 10: Histogram distributions of the saturation anomalies (in \%) of (a) helium and (b) neon.

Severinghaus (2007) for the North Pacific, but this due to our choice of solubility functions. Below the 
thermocline, there is a weak increasing trend in $\Delta$ Ne toward mid-depths followed by a slight decrease toward the bottom.

The three heaviest noble gases share a common pattern which becomes more pronounced with increasing atomic mass (i.e., $\mathrm{Ar}<\mathrm{Kr}<\mathrm{Xe}$ ). The bottom waters are characterized by a significantly negative saturation anomaly that is most pronounced in the west but also weakly evident as well in the Peru-Chile trench in the far-eastern end of the section. In the main thermocline, all three noble gases show positive anomalies overlain by a general decrease toward near zero values at the sea surface. Hamme and Severinghaus (2007) observed similar trends in their North Pacific profiles and proposed that the pattern of negative anomalies results from disequilibria in cooling water (due to limited air-sea exchange) during convective water mass renewal. Loose and Jenkins (2014) pointed to an additional mechanism associated with sub-basal glacial melting near Antarctica. Regardless of the relative importance of either phenomena, there is a clear gas-dependent signature in the incoming bottom water coupled with a general increasing trend in saturation anomaly upward.

In the broadest terms, one can regard the Pacific circulation as vertically partitioned into two roughly independent cells. The first is a deep overturning circulation that occurs as part of the global scale meridional overturning circulation (MOC) where water enters the Pacific basin below 3000-4000 m, upwells in the interior, and returns in the depth range of 1000-2000 m (Kuhlbrodt et al., 2007). The second, shallower circulation system consists of intermediate and subpolar mode waters (Yasuda, 1997; Talley, 2003; ludicone et al., 2007) overlain by the main thermocline and wind-driven circulation cells. Tracer observations and inverse models are consistent with little direct exchange between these two cells (Wijffels et al., 1996; Wijffels et al., 2001; Kuhlbrodt et al., 2007) so we are safe to restrict our discussion to the deep cell. In the context of this paper, we discuss only the deep (>1000 m depth) water noble gas patterns, and leave a discussion of the shallow features to a later manuscript (Jenkins et al., 2017).

Figure 11 depicts the composite depth profiles of saturation anomalies for the four heavier noble gases ( $\mathrm{Ne}, \mathrm{Ar}, \mathrm{Kr}$, and $\mathrm{Xe}$ ). With the exception of neon, they all show a consistent, monotonic upward increase in saturation anomaly (from $5500 \mathrm{~m}$ to $1000 \mathrm{~m}$ depths, see polynomial regression lines) that becomes progressively stronger from $\operatorname{Ar}(1.1 \%)$ through $\mathrm{Kr}(1.8 \%)$ to Xe (2.4\%). Ito and Deutsch (2006) argue that diapycnal mixing, working on the curvature of the solubility as a function of temperature $T$ would tend to increase the saturation state of an inert gas $C$ with time $t$ according to

$$
\begin{aligned}
& \frac{D \Delta C}{D t} \cong \Upsilon \kappa\left(\frac{\partial T}{\partial z}\right)^{2} \\
& \text { where } \Upsilon=\left(\frac{1}{C_{S}} \frac{\partial^{2} C_{S}}{\partial T^{2}}\right)
\end{aligned}
$$

where $\kappa$ is the diapycnal diffusivity, $z$ is vertical distance, $\Upsilon$ is the normalized solubility curvature as a function of temperature $(T)$, and $C_{S}$ is the gas solubility. If we imagine a uniform upwelling velocity $w$ over an advective-diffusive subrange (Munk, 1966) between $\sim 5500 \mathrm{~m}$ and $1000 \mathrm{~m}$, then one could argue that diapycnal mixing would increase gas saturation anomalies in proportion to the normalized solubility curvatures as in equation (5). We plot, in Figure 12, the observed increases in $\mathrm{Ar}$, $\mathrm{Kr}$, and $\mathrm{Xe}$ saturation 

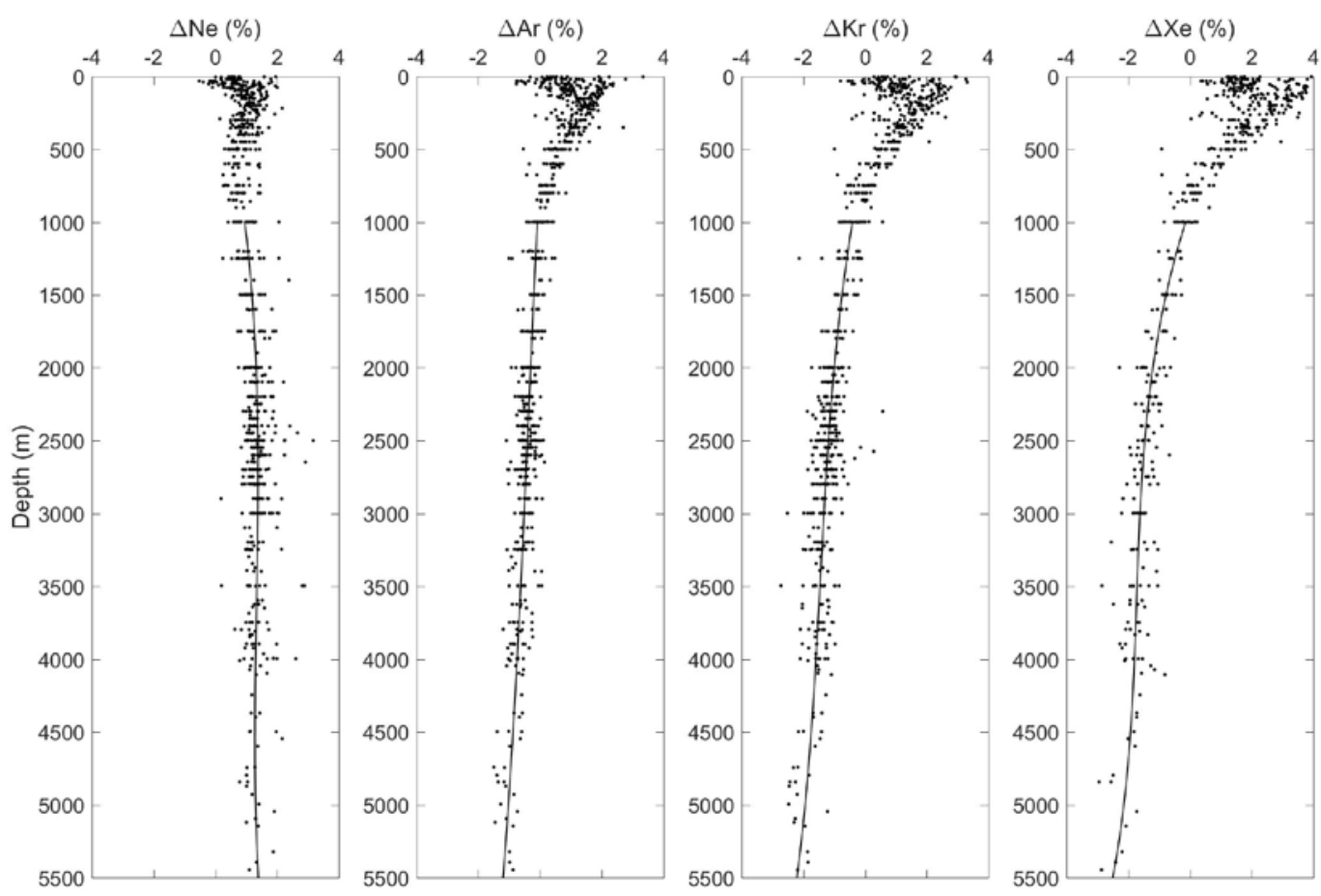

Figure 11: Composite profiles vs depth of saturation anomalies of $\mathrm{Ne}, \mathrm{Ar}, \mathrm{Kr}$, and Xe. A low order (cubic) polynomial fit to the data is included.

anomaly between 5500 and $1000 \mathrm{~m}$ obtained using a low order polynomial fit vs. depth (see solid curves in Figure 11) against their respective normalized solubility curvatures over the abyssal temperature range from 0.8 to $4.0^{\circ} \mathrm{C}$, namely $\Upsilon_{\mathrm{Ar}}=1.3 \times 10^{-3}, \Upsilon_{\mathrm{Kr}}=1.9 \times 10^{-3}$, and $\Upsilon_{\mathrm{Xe}}=2.6 \times 10^{-3}$. The correlation is is striking, and supports our supposition that the increase may in large part be due to the diapycnal mixing effects described in Equation (5).

With this in mind, it should be recognized that $\Delta \mathrm{He}$ and $\Delta \mathrm{Ne}$ should be similarly affected, but to a lesser extent due to their smaller solubility curvatures $\left(\Upsilon_{\mathrm{He}}=2.4 \times 10^{-4}\right.$ and $\left.\Upsilon_{\mathrm{Ne}}=3.8 \times 10^{-4}\right)$. Scaling against the observed increases for $\Delta \mathrm{Ar}, \Delta \mathrm{Kr}$, and $\Delta \mathrm{Xe}$, we predict maximum increases of $\sim 0.2 \%$ for $\Delta \mathrm{He}$ and $\sim 0.3 \%$ for $\Delta \mathrm{Ne}$. In conclusion, we argue that the apparent increase in saturation anomalies of the heavy noble gases between the incoming bottom waters and intermediate water depths is a signature of diapycnal mixing, and in effect results from a depression of the solubility expectation due to the positive curvature of the gas solubilities as a function of temperature.

In order to compensate for this effect on $\Delta \mathrm{Ne}$ and $\Delta \mathrm{He}$, we compare each sample's $\Delta \mathrm{Ar}, \Delta \mathrm{Kr}$, and $\Delta \mathrm{Xe}$ values to "reference" bottom water values (the latter obtained

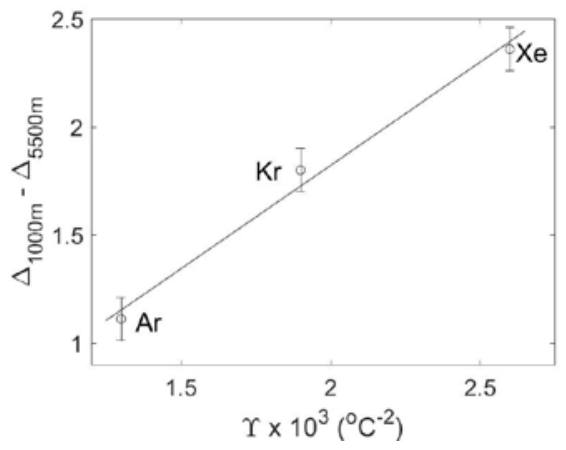

Figure 12: Saturation anomaly increase vs. normalized solubility curvature for $A r, K r$, and $\mathrm{Xe}$. 
from the low order polynomial regressions plotted in figure 11) at $5500 \mathrm{~m}$ depth of $-1.2 \%,-2.2 \%$, and $2.5 \%$ respectively. We use these differences to obtain an average curvature-scaled estimate of the diapycnal mixing induced perturbations in $\Delta \mathrm{He}$ and $\Delta \mathrm{Ne}$.

$$
\begin{aligned}
& \Delta \Delta \mathrm{Ne}=\left(3.8 \times 10^{-4}\right) \times \frac{1}{n} \sum_{i=1}^{n} \Upsilon_{i}^{-1} \Delta \Delta_{i} \\
& \Delta \Delta \mathrm{He}=\left(2.4 \times 10^{-4}\right) \times \frac{1}{n} \sum_{i=1}^{n} \Upsilon_{i}^{-1} \Delta \Delta_{i}
\end{aligned}
$$

where the summation is over $\Delta \mathrm{Ar}, \Delta \mathrm{Kr}$, and $\Delta \mathrm{Xe}$ for those samples measured by isotope dilution $(n=3)$, and over $\mathrm{Ar}$ $\mathrm{Kr}$ for the remainder $(n=2)$. In the latter case, the relatively poorer precision of the Xe measurements would have degraded the accuracy of the correction.

Figure 13 contains profiles of the magnitude of these correction factors as a function of depth. As expected, the correction is smallest in the deep water and increases upward toward intermediate depths. The maximum correction for $\mathrm{He}$ is about $0.2 \%$ and for $\mathrm{Ne}$ around 0.3 to $0.4 \%$. While it is challenging to assess what might be the uncertainty in the magnitude of this correction, their apparent scatter around the overall depth trend is of order $0.1 \%$, roughly consistent with error propagation calculations that include the measurement errors for
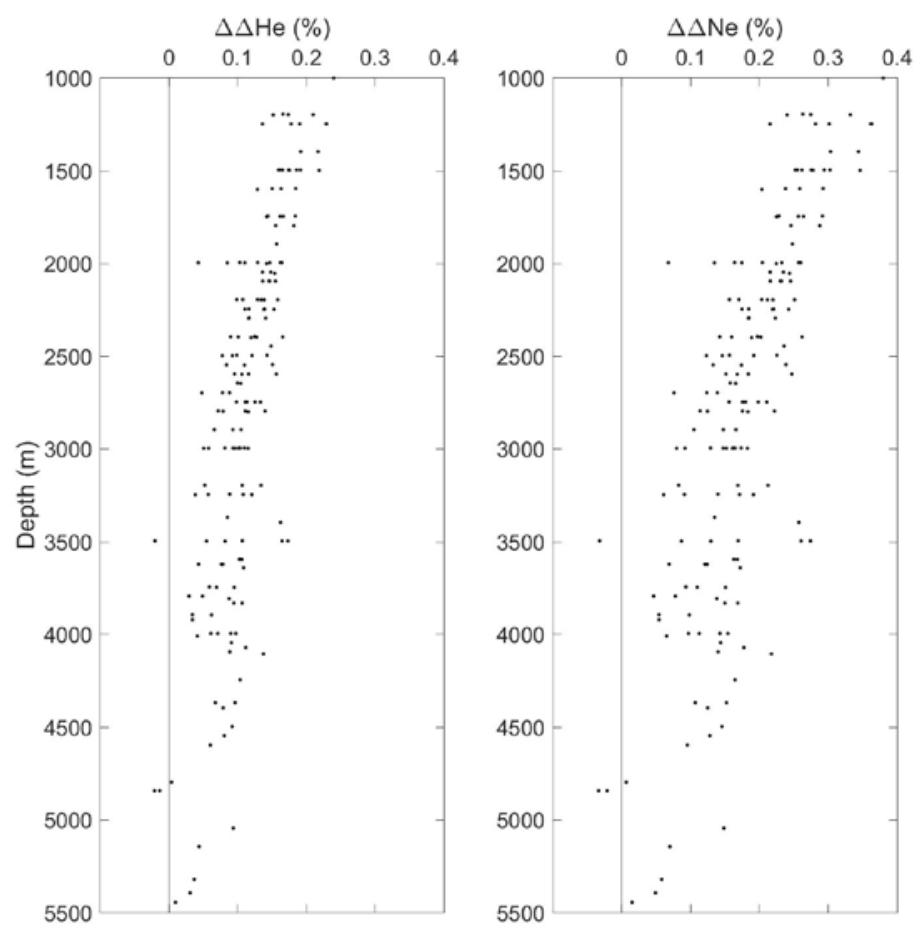

Figure 13: Composite profiles of the estimated diapycnal mixing effect for $\mathrm{He}$ (left) and $\mathrm{Ne}$ (right). $\Delta \mathrm{Ar}, \Delta \mathrm{Kr}$, and $\Delta \mathrm{Xe}$.

\section{d) Helium Isotope Ratios}

These considerations become important when we attempt to calculate the actual amount of hydrothermal ${ }^{3} \mathrm{He}$ (for the purposes of flux gauge calculations) and ${ }^{4} \mathrm{He}$, in order to separate out the non-atmospheric helium isotope ratios. To compute the non-atmospheric ${ }^{3} \mathrm{He}$ and ${ }^{4} \mathrm{He}$ abundances, we propose that the Measured (or total) isotope abundances $\left(\boldsymbol{C}_{\mathrm{M}}\right)$ are comprised of three components:

1. The Solubility equilibrium dissolved atmospheric component $\boldsymbol{C}_{\mathrm{s}}$

2. An excess Atmospheric component (due to bubble trapping, mixing, etc.) $\boldsymbol{C}_{\mathrm{A}}$

3. A non-atmospheric eXces $\mathbf{S}$ component (either hydrothermal $\mathrm{He}$ or tritiugenic ${ }^{3} \mathrm{He}$ ) $\boldsymbol{C}_{\mathrm{xs}}$. 
We can then write the excess (non-atmospheric) isotope components as

$$
\begin{aligned}
& C_{X S}\left({ }^{4} \mathrm{He}\right)=C_{M}\left({ }^{4} \mathrm{He}\right)-C_{S}\left({ }^{4} \mathrm{He}\right)-C_{A}\left({ }^{4} \mathrm{He}\right) \\
& C_{X S}\left({ }^{3} \mathrm{He}\right)=C_{M}\left({ }^{3} \mathrm{He}\right)-C_{S}\left({ }^{3} \mathrm{He}\right)-C_{A}\left({ }^{3} \mathrm{He}\right)
\end{aligned}
$$

The first terms on the right hand side are given by

$$
\begin{aligned}
& C_{M}\left({ }^{4} \mathrm{He}\right)=C(\mathrm{He}) \\
& C_{M}\left({ }^{3} \mathrm{He}\right)=1.384 \times 10^{-6}\left(1+\delta\left({ }^{3} \mathrm{He}\right) / 100\right) \times C(\mathrm{He})
\end{aligned}
$$

which includes the atmospheric ${ }^{3} \mathrm{He} /{ }^{4} \mathrm{He}$ ratio (Clarke et al., 1976). Note that since atmospheric helium is $\sim 99.9999 \%{ }^{4} \mathrm{He}$, we have $C_{M}\left({ }^{4} \mathrm{He}\right)=C(\mathrm{He})$.

The second terms are derived from the solubility as a function of potential temperature and salinity of each sample, combined with the helium isotope solubility fractionation factor $\alpha_{s}$ which is a function of temperature and salinity (Benson and Krause, 1980) and the atmospheric ${ }^{3} \mathrm{He} /{ }^{4} \mathrm{He}$ ratio:

$$
\begin{aligned}
& C_{S}\left({ }^{4} \mathrm{He}\right)=C_{S}(\mathrm{He}) \times\left(1+\frac{\Delta \Delta \mathrm{He}}{100}\right) \\
& C_{S}\left({ }^{3} \mathrm{He}\right)=\alpha_{S} \times 1.384 \times 10^{-6} \times C_{S}(\mathrm{He})
\end{aligned}
$$

and where $\Delta \Delta \mathrm{He}$ is our estimate of the saturation expectation depression due to diapycnal mixing (estimated from $\Delta \mathrm{Ar}, \Delta \mathrm{Kr}$, and $\Delta \mathrm{Xe}$ as described in the previous section) which must be added back in.

For the third terms, we construct a heuristic relationship to predict the atmospherically derived $\Delta \mathrm{He}$ produced by the combination of air bubble injection (e.g., Jenkins, 1988), thermal disequilibrium (Hamme and Severinghaus, 2007), and the effects of diapycnal mixing discussed in the last section. Given the similarities in colligative properties between $\mathrm{He}$ and $\mathrm{Ne}$, we use $\Delta \mathrm{Ne}$ as a predictor of the nonhydrothermal $\Delta \mathrm{He}$. We adopt an empirical relationship between deep water $\Delta \mathrm{Ne}$ and $\Delta \mathrm{He}$ in an area without significant hydrothermal helium contributions, namely the North Atlantic away from Mid Atlantic Ridge. Using recent data from the U.S. North Atlantic GEOTRACES GA03 cruise (Jenkins et al., 2014a; Jenkins et al., 2014b) we find a molar ratio of $0.22 \pm 0.01$ between excess $\mathrm{He}$ and excess $\mathrm{Ne}$ below $1000 \mathrm{~m}$ depth. The fact that this value is significantly lower than the atmospheric abundance ratio of 0.288 is a reflection of the intertwined effects of thermal disequilibrium (Hamme and Severinghaus, 2007) and partial vs. complete bubble injection processes (Jenkins, 1988; Stanley et al., 2009b; Liang et al., 2013) during water mass formation. This leads to an estimate of the non-hydrothermal helium excess:

$$
\begin{aligned}
& C_{A}\left({ }^{4} \mathrm{He}\right)=(0.22 \pm 0.01) \times \frac{\Delta \mathrm{Ne}-\Delta \Delta \mathrm{Ne}}{100} C_{S}(\mathrm{Ne}) \\
& C_{A}\left({ }^{3} \mathrm{He}\right)=1.384 \times 10^{-6} \times C_{A}\left({ }^{4} \mathrm{He}\right)
\end{aligned}
$$

where we have corrected $\Delta \mathrm{Ne}$ for the mixing-induced increase $(\Delta \Delta \mathrm{Ne})$ using observations of $\Delta \mathrm{Ar}, \Delta \mathrm{Kr}$, and $\Delta \mathrm{Xe}$ as described in the previous section. Note that the two correction factors ( $\Delta \Delta \mathrm{He}$ and $\Delta \Delta \mathrm{Ne}$ ) act 
in a somewhat compensatory fashion. That is, $\Delta \Delta \mathrm{He}$ serves to increase the value of $C_{S}$ while $\Delta \Delta \mathrm{Ne}$ reduces the contribution of $C_{A}$ in Equation (7).

The relative size of the uncertainty in the coefficient is small, corresponding to an equivalent uncertainty in $C_{A}{ }^{4} \mathrm{He}$ ) of $\sim 1 \mathrm{pmol} \mathrm{kg}^{-1}$ and in $\left.C_{A \mid}{ }^{3} \mathrm{He}\right)$ of $\sim 0.001 \mathrm{fmol} \mathrm{kg}^{-1}$. However, propagation of all potential biases, including measurement, model, and standardization errors, yields uncertainty of $7 \mathrm{pmol} / \mathrm{kg}$ in $C_{X S}\left({ }^{4} \mathrm{He}\right)$ and $0.010 \mathrm{fmol} / \mathrm{kg}$ in $\mathrm{C}_{\mathrm{xs}}\left({ }^{3} \mathrm{He}\right)$.

Values for excess ${ }^{3} \mathrm{He}\left(\Delta^{3} \mathrm{He}\right.$, in $\left.\mathrm{fmol} / \mathrm{kg}\right)$ and excess ${ }^{4} \mathrm{He}\left(\Delta^{4} \mathrm{He}\right.$, in $\left.\mathrm{pmol} / \mathrm{kg}\right)$ computed from Equation (7) are shown in Figure 13. Since the contour interval for $C_{x s}\left({ }^{3} \mathrm{He}\right)(0.2 \mathrm{fmol} / \mathrm{kg})$ is 20 times its error and the contour interval for $\mathrm{C}_{\mathrm{xs}}{ }^{4} \mathrm{He}(20 \mathrm{pmol} / \mathrm{kg})$ is only three times its error, the latter appears slightly more noisy. Nonetheless, the hydrothermal plume signature shows up clearly in both isotopes, suggesting the potential for a robust determination of the isotope ratio.

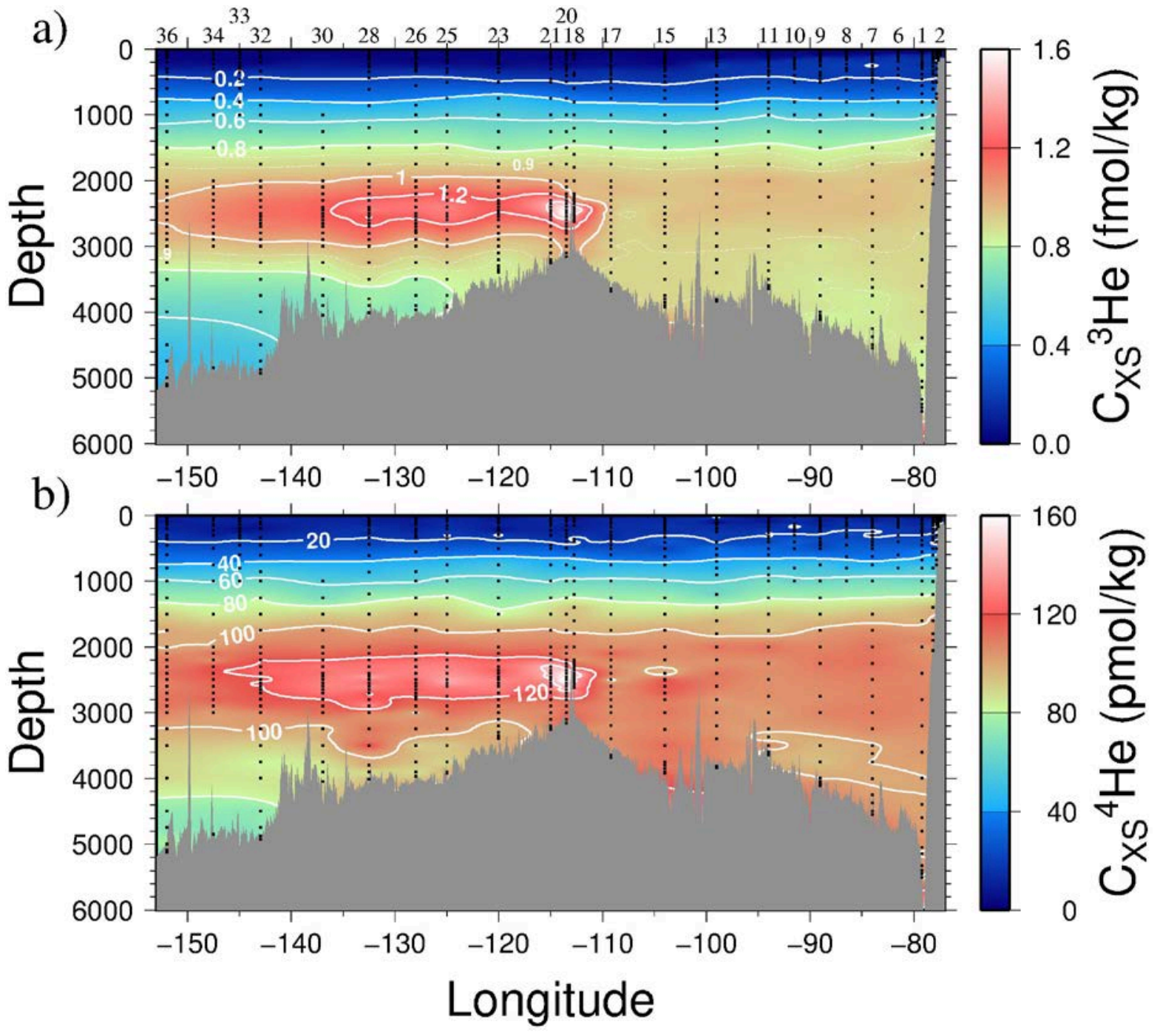

Figure 13: The zonal distributions of calculated excess helium (a) $C_{x s}{ }^{3} \mathrm{He}$ (upper panel, in $\mathrm{fmol} / \mathrm{kg}$ ) and (b) $\mathrm{C}_{X S^{4}} \mathrm{He}$ (lower panel, in pmol/kg). 


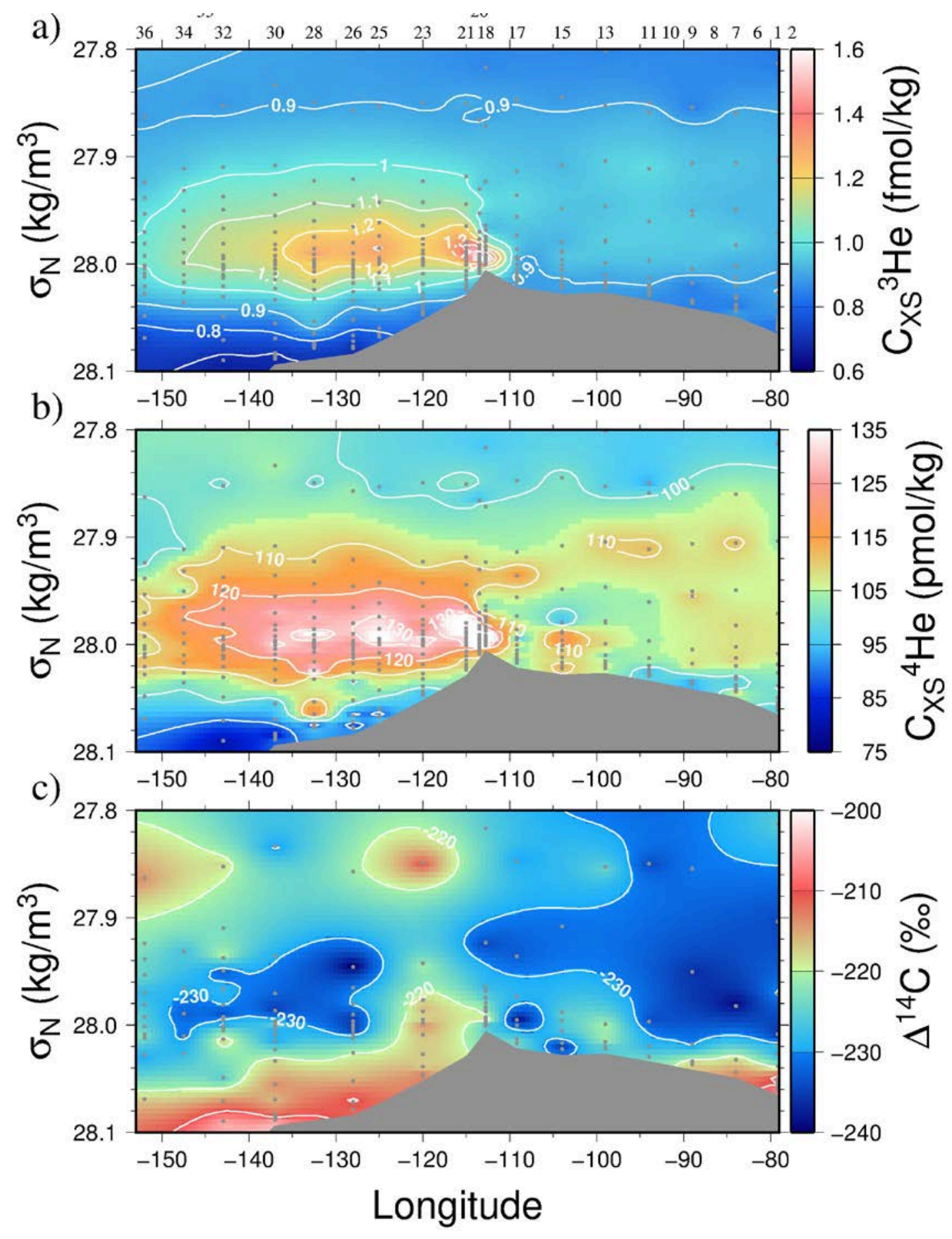

Figure 14: The zonal distributions of $(a) \mathrm{C}_{\mathrm{xs}}{ }^{3} \mathrm{He},(b) \mathrm{C}_{\mathrm{xs}}{ }^{4} \mathrm{He}$, and (c) $\Delta^{14} \mathrm{C}$ vs. neutral density. Note the difference color schemes from Figure 12 for the helium isotopes. Grey dots indicate sample locations.

Beyond the basin-scale contrast between younger, higher radiocarbon and lower hydrothermal helium bottom waters and the older, lower radiocarbon and more hydrothermal-rich mid-depth waters, there are other tantalizing structural similarities between $\mathrm{Cxs}^{4} \mathrm{He}$ and $\Delta^{14} \mathrm{C}$ (compare middle and bottom 
panels in Figure 14). In particular, east of the EPR $\mathrm{C}_{\mathrm{Xs}}{ }^{4} \mathrm{He}$ and $\Delta^{14} \mathrm{C}$ appear to be anticorrelated: there is a broad maximum in $\mathrm{C}_{\mathrm{xs}}{ }^{4} \mathrm{He}$ maximum and $\Delta^{14} \mathrm{C}$ minimum over the 27.9 to $28.0 \mathrm{~kg} / \mathrm{m}^{3}$ range, underlain by higher $\Delta^{14} \mathrm{C}$ and lower $\mathrm{C}_{\mathrm{xs}}{ }^{4} \mathrm{He}$ near-bottom waters east of $95^{\circ} \mathrm{W}$ and especially in the Peru-Chile trench. The high near-bottom $\mathrm{C}_{\mathrm{xs}}{ }^{4} \mathrm{He}$ near $105^{\circ} \mathrm{W}$ is reflected in lower $\Delta^{14} \mathrm{C}$. That is, the oldest waters (using radiocarbon as a clock) see the greatest excess ${ }^{4} \mathrm{He}$ anomalies, perhaps suggesting a more distributed input of radiogenic helium (rich in ${ }^{4} \mathrm{He}$ ) into Pacific deep waters. A similar anticorrelation is see in bottom waters west of the EPR, although the mid-depth structure in that there is $\mathrm{C}_{\mathrm{xs}}{ }^{4} \mathrm{He}$ strongly driven by the hydrothermal $\mathrm{C}_{x s}{ }^{3} \mathrm{He}$ distribution. Likely this is the contrasting signature of younger (higher radiocarbon), lest hydrothermally influenced bottom waters entering the Pacific from the south. Both $\mathrm{C}_{\mathrm{Xs}}{ }^{3} \mathrm{He}$ and $\mathrm{C}_{\mathrm{xs}}{ }^{4} \mathrm{He}$ behave similarly in the plume, especially with the $120^{\circ} \mathrm{W}$ narrowing and the $133^{\circ} \mathrm{W}$ downward deflection of isopleths below the core of the plume. The latter structure was evident in the Station 28 profile seen in Figure 4.

The average mid-depth (2250-2750 $\mathrm{m}$ ) isotopic ratio of excess helium as derived using the quantities obtained with Equation (7) is roughly 6.5 times the atmospheric ratio $\left(R_{a}\right)$, being as high as $7.1 R_{a}$ within the plume and as low as $6.1 R_{a}$ east of the EPR. This is an "aggregate" measure of the water column helium isotope ratio; not just because it is a depth average, but because it must result from mixing between a variety of end-members. We plot in this value as a function of longitude in Figure 15.

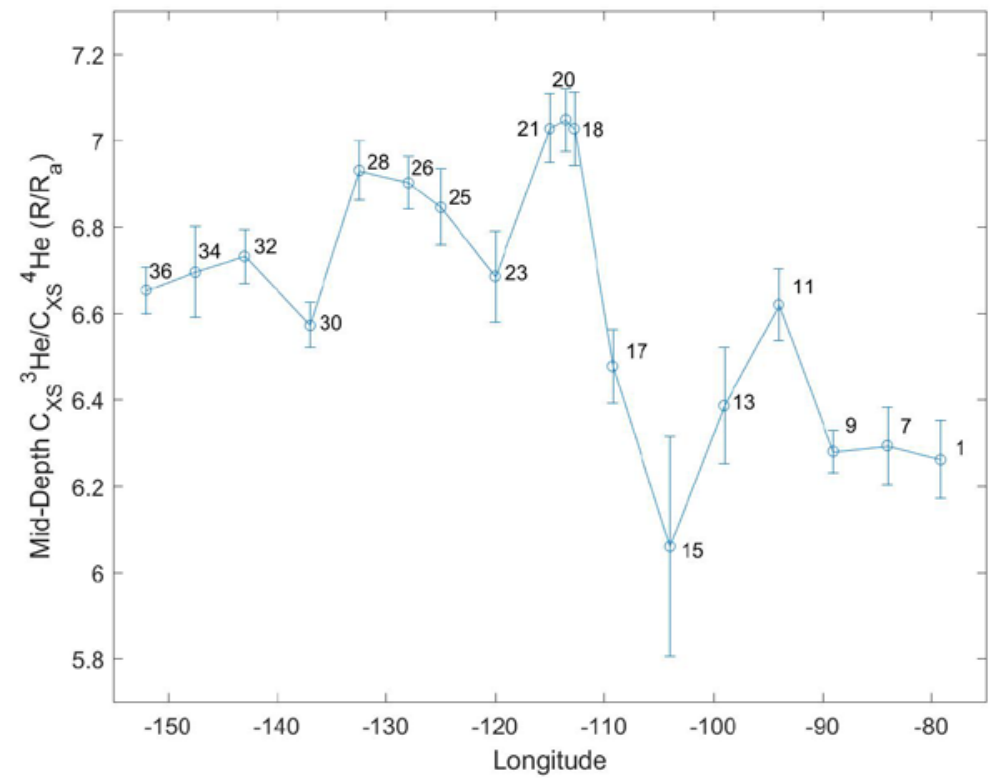

Figure 15: The mid-depth $(2250-2750 \mathrm{~m})$ average excess ${ }^{3} \mathrm{He} /{ }^{4} \mathrm{He}$ ratio.

There is an overall westward trend of decreasing ${ }^{3} \mathrm{He} /{ }^{4} \mathrm{He}$ ratio with distance from the ridge, due to mixing of an apparently higher ${ }^{3} \mathrm{He} /{ }^{4} \mathrm{He}$ ratio in the hydrothermal source with "background" levels of helium. Significant negative excursions relative to this trend occur at station $23\left(120^{\circ} \mathrm{W}\right)$ and to a lesser extent station $30\left(137^{\circ} \mathrm{W}\right)$. We propose that the decrease at 23 especially supports our conjecture that the locally lower $\delta^{3} \mathrm{He}$ is a result of mid-depth circulation from the south (a region of lower ${ }^{3} \mathrm{He} /{ }^{4} \mathrm{He}$ ) rather than modulation of the hydrothermal source. 
However, the "aggregate" ${ }^{3} \mathrm{He} /{ }^{4} \mathrm{He}$ plotted in Figure 15 results a summation of all possible contributions from a wide range of sources, influenced by circulation and mixing. We can obtain a better estimate in another way. Figure 16 shows the relationship between $C_{X S}\left({ }^{3} \mathrm{He}\right)$ and $C_{X S}\left({ }^{4} \mathrm{He}\right)$ both in the deep water to the east of the EPR (left panel) and inside the core of the hydrothermal plume as determined by the 1 $\mathrm{fmol} / \mathrm{kg}{ }^{3} \mathrm{He}$ isopleth (right panel). We restricted the analysis to tritium-free (and CFC-free) depths to avoid the possible contribution of bomb-tritium decay to ${ }^{3} \mathrm{He}$. The in situ decay of any ancient natural (cosmogenic) tritium (Weiss and Roether, 1980) could contribute no more than about $0.05 \mathrm{fmol} / \mathrm{kg}$ to the excess ${ }^{3} \mathrm{He}$, and would tend to appear as a constant offset to the data, thereby not affecting the slope of the ${ }^{3} \mathrm{He} v s .{ }^{4} \mathrm{He}$ relationship. We claim the latter because the MOC transit time from water mass formation regions to the deep Pacific (at least several centuries and likely close to a millenium, e.g., see Gebbie and Huybers, 2012) greatly exceeds the half-life of tritium.
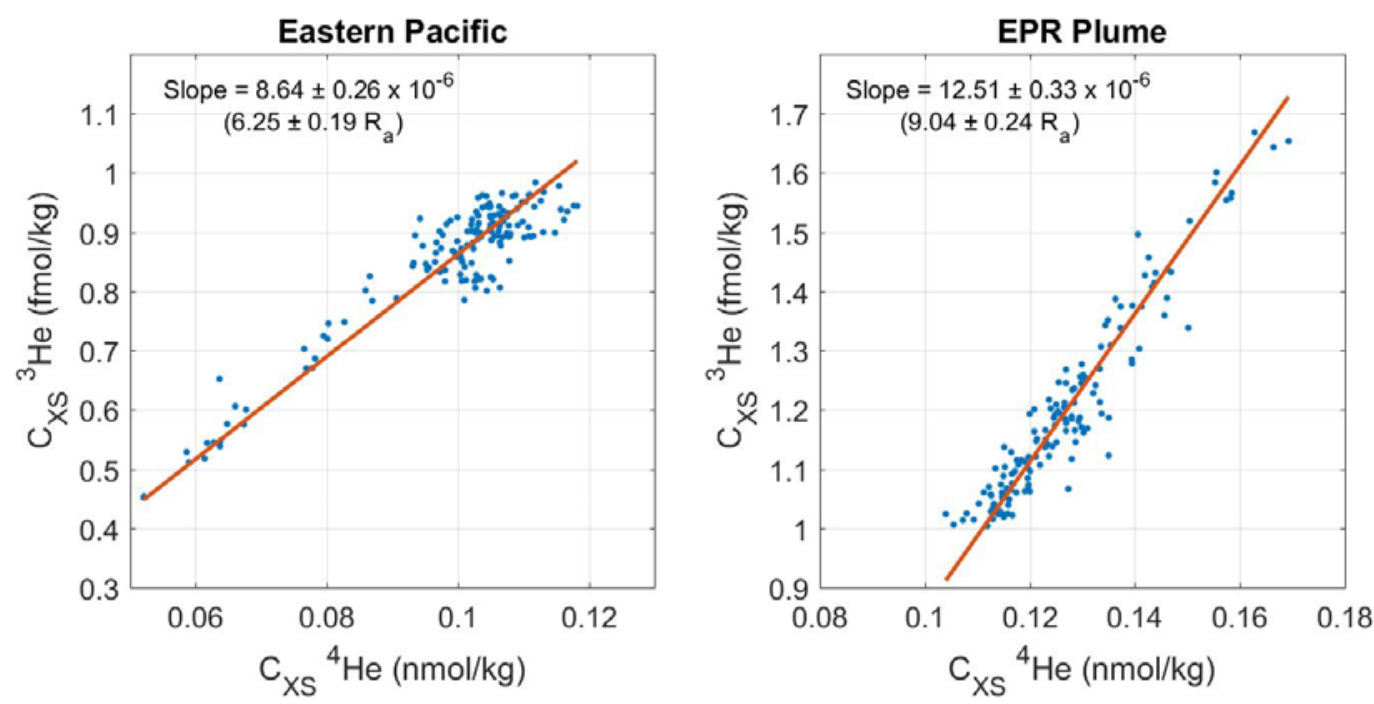

Figure 16: The relationship between non-atmospheric $\mathrm{C}_{x s}{ }^{3} \mathrm{He}$ and $\mathrm{C}_{\mathrm{xs}}{ }^{4} \mathrm{He}$ (a) east of the EPR (left panel) and (b) inside the volcanic ${ }^{3} \mathrm{He}$ plume as defined by the $1 \mathrm{fmol} / \mathrm{kg}$ isopleth (right panel).

The slopes of those relationships, determined by unweighted type II linear regression, show a remarkable regional difference. Expressed relative to $R_{a}$, the atmospheric ${ }^{3} \mathrm{He} /{ }^{4} \mathrm{He}$ ratio, the background excess helium east of the EPR has an isotope ratio of $6.25 \pm 0.19 R_{a}$ while the core of the plume is $9.04 \pm$ $0.24 \mathrm{R}_{\mathrm{a}}$. Both differ significantly from the "canonical" mid-ocean ridge basaltic value of $8 \mathrm{R}_{\mathrm{a}}$ (Kurz and Jenkins, 1981; Allegre et al., 1995) and direct measurements of the submarine hydrothermal sources (e.g., Jenkins et al., 1978).

The distinctly higher value of $9.04 \pm 0.24 R_{a}$ measured in the plume itself is consistent with the elevated ${ }^{3} \mathrm{He} /{ }^{4} \mathrm{He}$ values (up to $11 \mathrm{R}_{\mathrm{a}}$ ) seen in EPR MORBs just south of this section (Kurz et al., 2005) coupled with the dynamically expected anticyclonic flow induced by the hydrothermal buoyancy injection (Stommel, 1982). The Kurz et al study (2005) shows a positive excursion in MORB ${ }^{3} \mathrm{He} /{ }^{4} \mathrm{He}$ extending over 100-200 $\mathrm{km}$ of latitude along the EPR (see their Figure 3, noting that it is a plot of ${ }^{4} \mathrm{He} /{ }^{3} \mathrm{He}$ ). Thus the deep water anticyclone integrates this effluent as it travels northward along the EPR, then carries it westward as it turns near $15^{\circ} \mathrm{S}$. 
The background ${ }^{3} \mathrm{He} /{ }^{4} \mathrm{He}$ value of $6.25 \pm 0.19 \mathrm{R}_{\mathrm{a}}$ seen in the deep water east of the EPR is more challenging to explain. Inasmuch as the modal MORB ${ }^{3} \mathrm{He} /{ }^{4} \mathrm{He}$ ratio appears to be close to $8 \mathrm{R}_{\mathrm{a}}$, one would expect the bulk of hydrothermal/volcanic He emissions to reflect this value (Jenkins et al., 1978). The observed lower deep-water value may suggest a more diffuse/distributed flux of more radiogenic (lower ${ }^{3} \mathrm{He} /{ }^{4} \mathrm{He}$ ) helium arising from in situ $\mathrm{U}$ and Th radioactive chain decay in marine sediments and/or oceanic crust. The broad anticorrelation seen between $C_{X S}\left({ }^{4} \mathrm{He}\right)$ and $\Delta{ }^{14} \mathrm{C}$ in the eastern basin is strongly suggestive of such a distributed input. Coupled with estimates of the global ${ }^{3} \mathrm{He}$ flux of $\sim 550 \mathrm{~mol} / \mathrm{y}$ (Bianchi et al., 2010; Schlitzer, 2016; Holzer et al., 2017), a 20\% depression in the water column from the MORB source ratio could imply an additional radiogenic ${ }^{4} \mathrm{He}$ flux of order $10^{7} \mathrm{~mol} / \mathrm{y}$ globally. As a fraction of the regional hydrothermal helium flux, this estimate is consistent with conclusions of Fe- $\mathrm{C}_{\mathrm{Org}}$ modeling of the East Pacific Rise $9^{\circ} 50^{\prime} \mathrm{N}$ hydrothermal system. (German et al., 2015). This estimate is broadly similar to the analysis of Well et al (Well et al., 2001) but significantly smaller than that of Roether et al (Roether et al., 1998). The relatively clear imprint on the noble gas estimated $\mathrm{C}_{\mathrm{xs}}{ }^{4} \mathrm{He}$ suggests that more regional scale evaluations of that quantity may be useful for discerning the importance of this phenomenon. A future survey of ${ }^{3} \mathrm{He} /{ }^{4} \mathrm{He}$ values for major hydrothermal injection sites would be helpful in confirming or refuting this supposition.

\section{Conclusions}

We have documented a large tongue of hydrothermal ${ }^{3} \mathrm{He}$ in the South Pacific that is emanating westward at about $10-15^{\circ} \mathrm{S}$ and $2500 \mathrm{~m}$ depth for more than $4000 \mathrm{~km}$ away from the East Pacific Rise. The ${ }^{3} \mathrm{He}$ tongue exhibits an inflection to lower values situated at around $120^{\circ} \mathrm{W}$ (about $850 \mathrm{~km}$ from the plume source) that is also marked by reduced concentrations in other hydrothermal trace elements and isotopes. We investigated whether systematic variations downstream in the depth and neutral density of this tongue, combined with the dynamics of buoyant hydrothermal plumes, result from significant decade time-scale variations in venting intensity, but concluded that the required variations would be too large. This was also supported by the fact that the inflection was marked by a concomitant reduction in the aggregate ${ }^{3} \mathrm{He} /{ }^{4} \mathrm{He}$ ratio. We also discussed whether asymmetric diapycnal mixing could contribute to these changes and concluded that was also unlikely. Measurement of radiocarbon on this section also reveals significantly higher $\Delta^{14} \mathrm{C}$ (by around $15 \%$ ) at the location and depth of the anomaly, suggesting that this feature results from a meridional circulation displacement rather than a hiatus in hydrothermal injection. Given regional-scale distributions of radiocarbon and other properties, along with large-scale physics, we concluded that the origin of this water is likely around $30-35^{\circ} \mathrm{S}$ near the EPR. Thus a picture has emerged that this large, $4000 \mathrm{~km}$ hydrothermal ${ }^{3} \mathrm{He}$ tongue may not be a simple continuous "smoke plume" emanating from a single locale on the EPR.

The deep radiocarbon section supports the traditional view of Pacific abyssal circulation with the characteristic mid-depth minimum in $\Delta^{14} \mathrm{C}$ underlying both an increase upward of natural radiocarbon into the thermocline and the invading bomb radiocarbon signature. Below the mid-depth minimum we see the invasion of relatively younger waters from the south, both in the west and in the Peru-Chile trench on the eastern end of the section.

The deep distribution of dissolved helium is dominated by the injection of hydrothermal helium from the crest of the EPR, and exhibits a mid-depth westward pointing plume strongly resembling that of $\delta^{3} \mathrm{He}$. This results from the fact that the ${ }^{3} \mathrm{He} /{ }^{4} \mathrm{He}$ ratio of the hydrothermal effluent, although 
significantly higher that atmospheric, is finite. A bulk histogram of the helium saturation anomalies is bimodal, with the dominant hydrothermal peak centered at 7.5 to $8 \%$ and a second peak around 1 to $1.5 \%$ resulting from atmospheric bubble injection. Exclusive of helium, the deep distributions of dissolved noble gases reflected two distinct patterns. The distribution of the saturation anomaly $\Delta \mathrm{Ne}$ is relatively uniform (compared with helium and the heavy noble gases), with a largely random variation that is about twice measurement error about a mean value of $1.1 \%$. The heavier noble gas ( $\mathrm{Ar}, \mathrm{Kr}$, and $\mathrm{Xe})$ saturation anomalies show a distinctly different pattern, with the most negative values in the deep waters, a gradual increase upward toward positive values in the main thermocline, and then a general diminution toward zero at the surface. The magnitudes of these trends increase systematically from $\mathrm{Ar}$ through $\mathrm{Kr}$ to $\mathrm{Xe}$, and their pattern is quantitatively consistent with the effects of diapycnal mixing during upwelling. We developed a simple scaling equation to extend the effect to the light noble gases (He and $\mathrm{Ne}$ ).

We constructed an empirical relationship between the neon and helium saturation anomalies in hydrothermal-free deep waters and combined with the diapycnal mixing correction we predict the "background" saturation anomaly for helium. This allows us to separate out the concentrations of nonatmospheric ${ }^{3} \mathrm{He}$ and ${ }^{4} \mathrm{He}$. In this manner we are able to determine the ${ }^{3} \mathrm{He} /{ }^{4} \mathrm{He}$ ratio of the dispersing plume to be $9.04 \pm 0.24$ times the atmospheric ratio $\left(R_{a}\right)$. This is significantly above typical value of $8 R_{a}$ seen in mid ocean ridge basalts (MORB), but consistent with the relatively high values observed in MORB just south of $15^{\circ} \mathrm{S}$ on the EPR, presumably picked up by the anticyclonic $\beta$-plume driven middepth circulation. In contrast, we determine the "background" South Pacific abyssal ${ }^{3} \mathrm{He} /{ }^{4} \mathrm{He}$ ratio east of the EPR to be $6.25 \pm 0.19 \mathrm{R}_{\mathrm{a}}$, significantly below the average MORB ${ }^{3} \mathrm{He} /{ }^{4} \mathrm{He}$ value. Combined with the observed anticorrelation between $\mathrm{C}_{x s}{ }^{4} \mathrm{He}$ and $\Delta^{14} \mathrm{C}$ we must conclude that the depression in ${ }^{3} \mathrm{He} /{ }^{4} \mathrm{He}$ relative to modal MORB values results from an additional diffuse input of radiogenic helium from the decay of $U$ and Th in sediments and/or altered oceanic crust. Using the estimated ${ }^{3} \mathrm{He}$ hydrothermal flux of $\sim 550 \mathrm{~mol} / \mathrm{y}$ we estimate this flux to be of order $10^{7} \mathrm{~mol}{ }^{4} \mathrm{He}$ per year globally. Acknowledgements

We all owe a debt of gratitude to Bob Anderson and Gideon Henderson for making the GEOTRACES program a reality. We thank Don Rice for his long term vision and support. This work would not be possible without the skilled, hardworking staff of the Oceanic Data Facility, and the Captain and crew of the Thomas G. Thompson. We are also grateful to Jim Moffett and Greg Cutter for their role in the success of this expedition. We thank Paul Quay and Johnny Stutsman for providing the $\mathrm{CO}_{2}$ gas aliquots for ${ }^{14} \mathrm{C}$ analysis. The work was funded under National Science Foundation grant number OCE-1232991 for WJJ and OCE-1130870 for CRG. We are also grateful for the numerous critical and constructive comments made by the three reviews of this paper.

\section{References}

Allegre, C.J., Moreira, M. and Staudacher, T., 1995. ${ }^{4} \mathrm{He} /{ }^{3} \mathrm{He}$ dispersion and mantle convection. Geophysical Research Letters, 22(17): 2325-2328.

Axford, W.I., 1968. The polar wind and the terrestrial helium budget. Journal of Geophysical Research, 73: 6855-6859.

Baker, E.T. and Lupton, J.E., 1990. Changes in submarine hydrothermal $3 \mathrm{He} /$ heat ratios as an indicator of magmatic/tectonic activity. Nature, 346: 556-558. 
Baker, E.T. and Urabe, T., 1996. Extensive distribution of hydrothermal plumes along the superfast

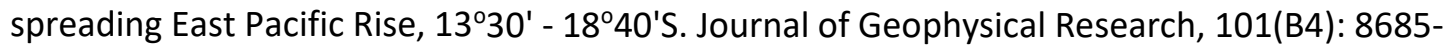
8695.

Benson, B.B. and Krause, D., Jr., 1980. Isotopic fractionation of helium during solution: a probe for the liquid state. Journal of Solution Chemistry, 9: 895-909.

Bianchi, D., Sarmiento, J.L., Gnanadesikan, A., Key, R.M., Schlosser, P. and Newton, R., 2010. Low helium flux from the mantle inferred from simulations of oceanic helium isotope data. Earth and Planetary Science Letters, 297: 379-386.

Bien, G.S., Rakestraw, N.W. and Suess, H.E., 1960. Radiocarbon concentration in Pacific Ocean water. Tellus, 12(4): 436-443.

Bien, G.S., Rakestraw, N.W. and Suess, H.E., 1965. Radiocarbon in the Pacific and Indian Oceans and its relation to deep water movements. Limnology and Oceanography, 10(Supplement): R25-R37.

Clarke, W.B., Beg, M.A. and Craig, H., 1969. Excess ${ }^{3} \mathrm{He}$ in the sea: evidence for terrestrial primordial helium. Earth and Planetary Science Letters, 6: 213-220.

Clarke, W.B., Jenkins, W.J. and Top, Z., 1976. Determination of tritium by spectrometric measurement of ${ }^{3} \mathrm{He}$. International Journal of Applied Radiation and Isotopes, 27: 515-525.

Craig, H., 1969. Abyssal carbon and radiocarbon in the Pacific. Journal of Geophysical Research, 74(23): 5491-5506.

Edmond, J.M., Measures, C., McDuff, R.E., Chan, L.H., Collier, R.W., Grant, B., Gordon, L.I. and Corliss, J.B., 1979. Ridge crest hydrothermal activity and the balances of the major and minor elements in the ocean: the Galapagos data. Earth and Planetary Science Letters, 46(1): 1-18.

Elderfield, H. and Schultz, A., 1996. Mid-ocean ridge hydrothermal fluxes and the chemical composition of the ocean. Annual Review of Earth and Planetary Sciences, 24: 191-224.

Feely, R.A., Baker, E.T., Marumo, K., Urabe, T., Ishibashi, J., Gendron, J., Lebon, G.T. and Okamura, K., 1996. Hydrothermal plume particles and dissolved phosphate over the superfast-spreading southern East Pacific Rise. Geochimica et Cosmochimica Acta, 60(13): 2297-2323.

Gebbie, G. and Huybers, P., 2012. The mean age of ocean waters inferred from Radiocarbon Observations: sensitivity to surface sources and accounting for mixing histories. Journal of Physical Oceanography, 42(2): 291-305.

German, C.R., Legendre, L.L., Sander, S.G., Niquil, N., Luther, G.W.I., Bharati, L., Han, X. and Le Bris, N., 2015. Hydrothermal Fe cycling and deep ocean organic carbon scavenging: model-based evidence for significant POC supply to seafloor sediments. Earth and Planetary Science Letters, 419: 143-153.

Hamme, R.C. and Severinghaus, J.P., 2007. Trace gas disequilibria during deep-water formation. DeepSea Research I, 54: 939-950.

Hautala, S.L. and Riser, S.C., 1989. A simple model of abyssal circulation, including effects of wind, buoyancy and topography. Journal of Physical Oceanography, 19(5): 596-611.

Hautala, S.L. and Riser, S.C., 1993. A nonconservative beta-spiral determination of the deep circulation in the Eastern South Pacific. Journal of Physical Oceanography, 23(9): 1975-2000.

Holzer, M., DeVries, T., Bianchi, D., Newton, R., Schlosser, P. and Winckler, G., 2017. Objective estimates of mantle ${ }^{3} \mathrm{He}$ in the ocean and implications for constraining the deep ocean circulation. Earth and Planetary Science Letters, 458(2): 305-314.

Ito, T. and Deutsch, C., 2006. Understanding the saturation state of argon in the thermocline: the role of air-sea gas exchange and diapycnal mixing. Global Biogeochemical Cycles, 20(GB3019): doi:10.1029/2005GB002655.

Ito, T., Deutsch, C., Emerson, S. and Hamme, R.C., 2007. Impact of diapycnal mixing on the saturation state of argon in the subtropical North Pacific. Geophysical Research Letters, 34(L09602): doi:10.1029/2006GL029209. 
ludicone, D., Rodgers, K.B., Schopp, R. and Madec, G., 2007. An exchange window for the injection of Antarctic Intermediate Water into the South Pacific. Journal of Physical Oceanography, 37(1): 31-49.

Jackett, D.R. and McDougall, T.J., 1997. A neutral density variable for the world's oceans. Journal of Physical Oceanography, 27(2): 237-263.

Jenkins, W.J., 1988. The use of anthropogenic tritium and $3 \mathrm{He}$ to study subtropical gyre ventilation and circulation. Philosophical Transactions of the Royal Society (London), A325: 43-61.

Jenkins, W.J. and Edmond, J.M., 1983. Advances in Marine Chemistry 1979-1982. Review of Geophysics and Space Physics, 21: 1233-1245.

Jenkins, W.J., Edmond, J.M. and Corliss, J.B., 1978. Excess ${ }^{3} \mathrm{He}$ and ${ }^{4} \mathrm{He}$ in Galapagos submarine hydrothermal waters. Nature, 272: 156-158.

Jenkins, W.J., Lott, D.E.I., Cahill, K.L., Goudreau, J. and Longworth, B.E., 2017. The shallow distributions of helium isotopes, tritium, radiocarbon, and noble gases along the U.S. GEOTRACES South Pacific zonal transect (GP16). Marine Chemistry, This Issue.

Jenkins, W.J., Lott, D.E.I., Longworth, B.E., Curtice, J.M. and Cahill, K.E., 2014a. The distributions of helium isotopes and tritium along the U.S. GEOTRACES North Altantic Sections (GEOTRACES GA03). Deep Sea Research Part II: Topical Studies in Oceanography, http://dx.doi.org/10.1016/j.dsr2.2014.11.017i.

Jenkins, W.J., Smethie, W.M.J., Boyle, E.A. and Cutter, G.A., 2014b. Water mass analysis for the U.S. GEOTRACES (GA03) North Atlantic Sections. Deep Sea Research Part II: Topical Studies in Oceanography, http://dx.doi.org/10.1016/i.dsr2.2014.11.018i.

Johnson, G.C. and Talley, L.D., 1997. Deep tracer and dynamical plumes in the tropical Pacific Ocean. Journal of Geophysical Research, 102(C11): 24953-24964.

Key, R.M., 1996. WOCE Pacific Ocean radiocarbon program. Radiocarbon, 38(3): 415-423.

Key, R.M., Quay, P., Jones, G.A., McNichol, A.P., Von Reden, K. and Schneider, R.J., 1996. WOCE AMS radiocarbon I: Pacific Ocean results (P6, P16 and P17). Radiocarbon, 38(3): 425-518.

Koblinksy, C.J., 1990. The global distribution of $f / h$ and the barotropic response of the ocean. Journal of Geophysical Research-Oceans, 95(C3): 3213-3218.

Kuhlbrodt, T., Griesel, A., Montoya, M., Levemann, A., Hofmann, M. and Rahmstorf, S., 2007. On the driving processes of the Atlantic meridional overturning circulation. Reviews of Geophysics, 45(RG2001): doi:10.1029/2004RG000166.

Kurz, M.D. and Jenkins, W.J., 1981. The distribution of helium in oceanic basalt glasses. Earth and Planetary Science Letters, 53: 41-54.

Kurz, M.D., Moreira, M., Curtice, J., Lott, D., III, Mahoney, J. and Sinton, J.M., 2005. Correlated helium, neon, and melt production on the super-fast spreading East Pacific Rise near $17 \mathrm{~S}$. Earth and Planetary Science Letters, 232: 125-142.

Ledwell, J.R., Montgomery, E.T., Polzin, K.L., St. Laurent, L.C., Schmitt, R.W. and Toole, J.M., 2000. Evidence for enhanced mixing over rough topography in the abyssal ocean. Nature, 403(6766): 179-182.

Liang, J.-H., Deutsch, C., McWilliams, J.C., Baschek, B., Sullivan, P.P. and Chiba, D., 2013. Parameterizing bubble-mediated air-sea gas exchange and its effect on ocean ventilation. Global Biogeochemical Cycles, 27(3): 894-905.

Lonsdale, P., 1976. Abyssal circulation of the southeastern Pacific and some geological implications. Journal of Geophysical Research, 81(6): 1163-1176.

Loose, B. and Jenkins, W.J., 2014. The five stable noble gases are sensitive and unambiguous tracers of glacial meltwater. Geophysical Research Letters, 41(8): 2835-2841.

Lupton, J.E. and Craig, H., 1981. A major helium-3 source at 15 S on the East Pacific Rise. Science, 214(4516): 13-18. 
Lupton, J.E. and Jenkins, W.J., 2017. Evolution of the South Pacific helium plume over the past 3 decades. Geochemistry Geophysics Geosystems, In preparation.

Lupton, J.E., Pyle, D.G., Jenkins, W.J., Greene, R. and Evans, L., 2003. Evidence for an extensive hydrothermal plume in the Tonga-Fiji region of the South Pacific. Geochemistry, Geophysics, Geosystems, 5: Q01003.

Matsumoto, K., 2007. Radiocarbon-based circulation age of the world oceans. Journal of Geophysical Research-Oceans, 112(C09004): doi:10.1029/2007JC004095.

McDougall, T.J., 1990. Bulk properties of "hot smoker" plumes. Earth and Planetary Science Letters, 99: 185-194.

Morton, B.R., Taylor, G.I. and Turner, G.S., 1956. Turbulent gravitational convection from maintained and instantaneous sources. Proceedings of the Royal Society, 234: 1-23.

Munk, W.H., 1966. Abyssal recipes. Deep-Sea Research, 13: 707-730.

Ostlund, H.G. and Stuiver, M., 1980. GEOSECS Pacific Radiocarbon. Radiocarbon, 22(1): 25-53.

Patterson, T.N.L., 1968. Escape of atmospheric helium by nonthermal processes. Reviews of Geophysics, 6(4): 553-557.

Pedlosky, J., 1979. Geophysical Fluid Dynamics. Springer-Verlag, New York, 624 pp.

Peters, B., Casciotti, K.L., Jenkins, W.J., Swift, J.H., German, C.R., Moffett, J., Cutter, G. and Brzezinski, M., 2017. Water mass analysis of the 2013 U.S. GEOTRACES Eastern Tropical Zonal Transect (GP16). Marine Chemistry(This Issue): Under Review.

Polzin, K.L., Toole, J.M., Ledwell, J.R. and Schmitt, R.W., 1997. Spatial variability of turbulent mixing in the abyssal ocean. Science, 276: 93-96.

Reid, J.L., 1982. Evidence of the effect of heat flux from the East Pacific Rise upon the characteristics of the mid-depth waters. Geophysical Research Letters, 9(4): 381-384.

Reid, J.L., 1986. On the total geostrophic circulation of the South Pacific Ocean: flow patterns, tracers and transports. Progress in Oceanography, 16(1): 1-61.

Resing, J.A., Sedwick, P.N., German, C.R., Jenkins, W.J., Moffett, J.W., Sohst, B.M. and Tagliabue, A., 2015. Basin-Scale transport of hydrothermal dissolved metals across the South Pacific Ocean. Nature, 523(9 July 2015): 203-206.

Roether, W., Well, R., Putzka, A. and Ruth, C., 1998. Component separation of oceanic helium. Journal of Geophysical Research, 103(C12): 27931-27946.

Roshan, S., Wu, J. and Jenkins, W.J., 2016. Long-range transport of hydrothermal dissolved $\mathrm{Zn}$ in the tropical South Pacific. Marine Chemistry, 183(1): 25-32.

Schlitzer, R., 2007. Assimilation of radiocarbon and chlorofluorocarbon data to constrain deep and bottom water transports in the world ocean. Journal of Physical Oceanography, 37(2): 259-276.

Schlitzer, R., 2016. Quantifying He fluxes from the mantle using multi-tracer data assimilation. Philosophical Transactions of the Royal Society of London Series a-Mathematical Physical and Engineering Sciences, In Press.

Shimmield, G.B. and Price, N.B., 1988. The scavenging of U, ${ }^{230} \mathrm{Th}$ and ${ }^{231} \mathrm{~Pa}$ during pulsed hydrothermal activity at $20^{\circ}$ S, East Pacific Rise. Geochimica et Cosmochimica Acta, 52(3): 669-377.

Speer, K.G., 1989. A forced baroclinic vortex around a hydrothermal plume. Geophysical Research Letters, 16(5): 461-464.

Speer, K.G. and Rona, P.A., 1989. A model of an Atlantic and Pacific hydrothermal plume. Journal of Geophysical Research, 94: 6213-6220.

Stanley, R.H.R., 2007. A Determination of Air-Sea Gas Exchange Processes and Upper Ocean Biological Production From Five Noble Gases and Tritiugenic Helium-3, MIT-WHOI Joint Program in Chemical Oceanography, Woods Hole, MA, 224 pp. 
Stanley, R.H.R., Baschek, B., Lott, D.E.I. and Jenkins, W.J., 2009a. A new automated method for measuring noble gases and their isotopic ratios in water samples. Geochemistry Geophysics Geosystems, 10(5): Q05008, doi:10.1029/2009GC002429.

Stanley, R.H.R., Jenkins, W.J. and Doney, S., 2006. Quantifying seasonal air-sea gas exchange processes using a noble gas time-series: a design experiment. Journal of Marine Research, 64: 267-295.

Stanley, R.H.R., Jenkins, W.J., Lott, D.E.I. and Doney, S.C., 2009b. Noble gas constraints on air-sea gas exchange and bubble fluxes. Journal of Geophysical Research-Oceans, 114(C11020): doi:10.1029/2009JC005396.

Stommel, H., 1982. Is the South Pacific helium-3 plume dynamically active? Earth and Planetary Science Letters, 61: 63-67.

Stommel, H. and Aarons, A.B., 1960. On the abyssal circulation of the world ocean - II. An idealized model of the circulation pattern and amplitude in ocean basins. Deep-Sea Research, 6: 217-233.

Stoney, G.J., 1905. Escape of gases from the atmosphere. Monthly Weather Review, 7(January): 6-9.

Talley, L.D., 2003. Shallow, intermediate, and deep overturning components to the global heat budget. Journal of Physical Oceanography, 33(3): 530-560.

Thurnherr, A.M., Ledwell, J.R., Lavelle, J.W. and Mullineaux, L.S., 2011. Hydrography and circulation near the crest of the East Pacific Rise between 9 and 10N. Deep-Sea Research I, 58: 365-376.

Turekian, K.K., 1959. The terrestrial economy of helium and argon. Geochimica et Cosmochimica Acta, 17: 37-43.

Weiss, R.F., 1971. Solubility of helium and neon in water and seawater. Journal of Chemical Engineering Data, 16(2): 235-241.

Weiss, W.M. and Roether, W., 1980. The rates of tritium input to the world oceans. Earth and Planetary Science Letters, 49: 435-446.

Well, R., Lupton, J.E. and Roether, W., 2001. Crustal helium in deep Pacific Waters. Journal of Geophysical Research, 106(C7): 14165-14177.

Wessel, P. and Smith, W.H.F., 2008. The Generic Mapping Tool (GMT) Version 4.3.1 Technical Reference and Cookbook. School of Ocean and Earth Science and Technology, University of Hawaii at Manoa, Honolulu, pp. 196.

Wijffels, S.E., Toole, J.M., Bryden, H.L., Fine, R.A., Jenkins, W.J. and Bullister, J.L., 1996. The water masses and circulation at $10^{\circ} \mathrm{N}$ in the Pacific. Deep-Sea Research I, 43(4): 501-544.

Wijffels, S.E., Toole, J.M. and Davis, R.E., 2001. Revisiting the South Pacific subtropical circulation: a synthesis of WOCE observations along 32 S. Journal of Geophysical Research, 106(C9): 1948119513.

Yasuda, I., 1997. The origin of North Pacific Intermediate Water. Journal of Geophysical ResearchOceans, 102(C1): 893-909.

Young, C. and Lupton, J.E., 1983. An ultratight fluid sampling system using cold-welded copper tubing. EOS Transactions AGU, 64: 735. 